\title{
Role of Peroxisome Proliferator-Activated Receptors (PPARs) in Energy Homeostasis of Dairy Animals: Exploiting Their Modulation through Nutrigenomic Interventions
}

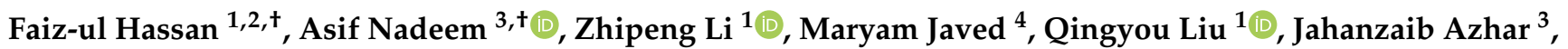 \\ Muhammad Saif-ur Rehman ${ }^{2}$, Kuiqing Cui ${ }^{1, *}$ and Saif ur Rehman ${ }^{1, *}$ (i) \\ 1 State Key Laboratory for Conservation and Utilization of Subtropical Agro-Bioresources, Guangxi University, \\ Nanning 530005, China; f.hassan@uaf.edu.pk (F.-u.H.); zp.li@gxu.edu.cn (Z.L.); qyliu-gene@gxu.edu.cn (Q.L.) \\ 2 Institute of Animal and Dairy Sciences, Faculty of Animal Husbandry, University of Agriculture, \\ Faisalabad 38040, Pakistan; shsaifurrehman@yahoo.com \\ 3 Department of Biotechnology, Virtual University of Pakistan, Lahore 54000, Pakistan; \\ asif.nadeem@vu.edu.pk (A.N.); jahanzaib.azhar@vu.edu.pk (J.A.) \\ 4 Institute of Biochemistry and Biotechnology, University of Veterinary and Animal Sciences Lahore, \\ Lahore 54000, Pakistan; Maryam.javed@uvas.edu.pk \\ * Correspondence: kqcui@gxu.edu.cn (K.C.); Saif_ali28@yahoo.com (S.u.R.) \\ + These authors contributed equally.
}

Citation: Hassan, F.-u.; Nadeem, A.;

Li, Z.; Javed, M.; Liu, Q.; Azhar, J.;

Rehman, M.S.-u.; Cui, K.; Rehman, S.u. Role of Peroxisome ProliferatorActivated Receptors (PPARs) in Energy Homeostasis of Dairy

Animals: Exploiting Their

Modulation through Nutrigenomic Interventions. Int. J. Mol. Sci. 2021, 22, 12463. https://doi.org/10.3390/ ijms222212463

Academic Editors: Walter Wahli and Manuel Vázquez-Carrera

Received: 29 September 2021

Accepted: 16 November 2021

Published: 18 November 2021

Publisher's Note: MDPI stays neutral with regard to jurisdictional claims in published maps and institutional affiliations.

Copyright: () 2021 by the authors. Licensee MDPI, Basel, Switzerland. This article is an open access article distributed under the terms and conditions of the Creative Commons Attribution (CC BY) license (https:// creativecommons.org/licenses/by/ $4.0 /)$.

\begin{abstract}
Peroxisome proliferator-activated receptors (PPARs) are the nuclear receptors that could mediate the nutrient-dependent transcriptional activation and regulate metabolic networks through energy homeostasis. However, these receptors cannot work properly under metabolic stress. PPARs and their subtypes can be modulated by nutrigenomic interventions, particularly under stress conditions to restore cellular homeostasis. Many nutrients such as polyunsaturated fatty acids, vitamins, dietary amino acids and phytochemicals have shown their ability for potential activation or inhibition of PPARs. Thus, through different mechanisms, all these nutrients can modulate PPARs and are ultimately helpful to prevent various metabolic disorders, particularly in transition dairy cows. This review aims to provide insights into the crucial role of PPARs in energy metabolism and their potential modulation through nutrigenomic interventions to improve energy homeostasis in dairy animals.
\end{abstract}

Keywords: nuclear receptors; PPARs; nutrigenomics; energy homeostasis; dairy animals

\section{Introduction}

Dairy animals provide milk and dairy products, which are considered some of the most important sources of nutrients for the human diet globally. Dairy production is the key element of sustainable agriculture in the tropics and subtropics. The rapidly increasing human population urges for consolidated efforts to ensure the abundant future availability of milk and dairy products. Therefore, problems and challenges associated with milk production and dairy animal health should be addressed to enhance the production of animals. Dairy animals experience diverse types of stress at different production stages in which the transition period is one of the most stressful stages in the life of dairy cattle. During the transition period and other stressful stages, the metabolic health of the animal is compromised, resulting in enhanced production of non-esterified fatty acids (NEFA) and ketone bodies $(\mathrm{kb})$. Other major conditions associated with these stress conditions include insulin resistance, low blood sugar levels and inflammation [1], which lead to toxicity, fatty liver, ketosis and other metabolic syndromes, ultimately reducing the performance of dairy animals [2].

Nuclear receptors are known to regulate physiological events of metabolism and control the homeostasis of glucose and lipid metabolism. They are also implicated in 
mediating the long-term effects of early environmental and nutritional experiences on the onset of chronic metabolic disorders in humans and animals [3]. Nuclear receptors belong to a family of ligand-regulated transcription factors that are activated by steroid hormones, such as progesterone, estrogen, and different other lipid-soluble signals such as oxysterols, thyroid hormone, and retinoic acid [4]. In contrast to other messengers, ligands are one of the intercellular messengers that can cross the plasma membrane barrier and directly interact with nuclear receptors instead of interacting with cells surface receptors. These nuclear receptors, once activated, can directly regulate the transcription of respective genes and control many biological processes, including the reproduction, development, proliferation of cells, and metabolism. Despite the fact that the nuclear receptors primarily work as transcription factors, but some have additionally been found to regulate the function of cells inside the cytoplasm [5]. More than 50 nuclear receptors are being reported in human genomes $[4,6]$. Ligands for these have been discovered, except for a few "orphan receptors" [7]. Major nuclear receptors with more comprehensive experimental data and their ligands are summarized in Table 1.

Table 1. Nuclear receptors along with their ligands [8].

\begin{tabular}{ccc}
\hline Receptor Name & Abbreviation & Ligand \\
\hline Progesterone receptor & PR & Progesterone \\
Estrogen receptor & ER & Estrogen \\
Liver X receptor & LXR & Oxysterols \\
Vitamin D3 receptor & VDR & Vitamin D3 \\
Androgen receptor & AR & Testosterone \\
Glucocorticoid receptor & GR & Cortisol \\
Thyroid hormone receptor & TR & Thyroid hormone \\
Retinoic acid-related receptor & RXR & Rexinoids \\
Mineralocorticoid receptor & MR & Aldosterone \\
Peroxisome proliferator activated receptor g & PPAR $\gamma$ & Fatty acid Metabolites \\
Retinoid orphan receptor & ROR & $?$ \\
Estrogen-related receptor & ERR & $?$ \\
\hline
\end{tabular}

All of the nuclear receptors have a common structure comprised of the highly variable amino-terminal domain that incorporates a few particular regions of transactivation (the A/B domain, also referred to as AF1 for activation function 1), a central conserved DNAbinding domain that contains two $\mathrm{Zn}$ fingers (the $\mathrm{C}$ domain), a short region responsible for nuclear localization (the D domain), and a large fairly well-conserved carboxy-terminal ligand-binding domain (the E domain, or LBD) that contributes to interactions of the subset of nuclear receptors that form heterodimers [4]. Further, a highly variable carboxy-terminal tail (the F domain) that in most cases has unknown functions is also present, as shown in Figure 1.

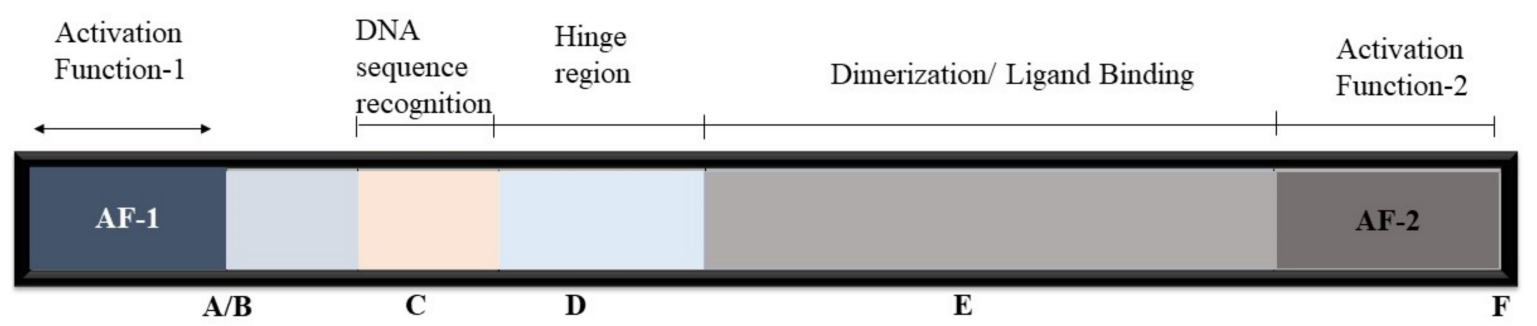

Figure 1. General basic association of atomic receptors [9]. Letters from A to F represented the domains of nuclear receptors from N-end to C-end.

Research studies on metabolic syndromes have identified a close connection between metabolic abnormalities and nuclear receptors, including PPARs, farnesoid $X$ receptors (FXRs), liver X receptors (LXRs) and glucocorticoid receptors (GRs) [3]. PPARs are widely 
studied nuclear receptors that are known to regulate and control metabolic changes both in humans and animals. Essentially, PPARs were first identified as novel members of the nuclear receptors from Xenopus frogs [10] and exhibited to induce the multiplication of peroxisomes in the cells. The PPAR $\alpha$ was the first member of these receptors that was identified in mammals during the analysis of molecular targets for liver peroxisome proliferators [11]. The characterization of the PPARA (encoding PPAR $\alpha$ ) gene in adult mice revealed that PPAR $\alpha$ found in humans and dairy animals is abundantly expressed in the liver, heart and kidney. After the discovery of PPAR $\alpha$, the other isotypes were also discovered, including PPAR $\gamma$ and PPAR $\beta / \delta$ [10]. The PPARs form heterodimers and function with the retinoid-X-receptor (RXR). Once a specific ligand binds to receptor dimer, it induces the covalent modification in the structure of PPARs, which activates these nuclear receptors [12]. The activated dimer PPAR/RXR binds to the PPAR response element, which is a specific DNA sequence in the promoter region of target genes, leading to the control of their expression. The PPAR response element is a hexanucleotide (AGGTCA) repeat separated by only a single nucleotide and varies for each PPAR member. All the members of PPARs are activated by the specific ligand concentrations (usually in $\mu \mathrm{M}$ range) both in the case of humans and ruminants [13].

A literature survey showed that information regarding the role of PPARs in lipid metabolism, the regulation of the expression of different genes and proteins and tissue distribution is mainly available in humans compared to dairy animals. However, Bionaz et al. analyzed the relative distribution of PPARs in bovine tissues of dairy cows and bovine cell lines through gene expression analysis by qPCR [14]. Their findings showed that the overall relative distribution of PPARs in dairy animals is quite similar to other species. Later, some studies also showed the relative distribution of PPARs in different organs of dairy animals, including rumen, adipose tissue, liver, kidney, lungs and mammary tissues. The biological and metabolic roles of PPARs have shown that they are the major molecules that regulate energy homeostasis [15], and hence, they are ideal candidates to address metabolic disorders in dairy animals through nutritional interventions.

\section{Nuclear Receptors' Mode of Action}

The potential mode of action of nuclear receptors is a prerequisite to better understanding the role of PPARs in energy homeostasis. The nuclear receptors can control transcriptional events by exerting a positive effect directly or by repressing regulated promoters. The protein-protein interactions can mediate a repressive effect on other signaling pathways under the regulation of transcription factors such as AP-1, NF-kappa-B, or C/EBP [9]. Figure 2 describes the involved elements and the processes that elicit the biological response.

\subsection{Transcriptional Activation}

Generally, transcription activation includes ligand-dependent conformational modifications of the chromatin REs-associated nuclear receptors, activating corepressor complex discharge and the successive deployment of coactivator complexes that alter the chromatin structure and facilitate the transcription initiation complex's assembly at the promoter regions. Numerous NR coactivators have been identified, and the repertoire is unique to a few cell types, signals, and genes. Therefore, the agonists binding activates the transfer of corepressors for coactivators critical for the transcription activation process. Moreover, the ligand-dependent interaction of NR corepressors, such as LCoR and RIP140, through LXXLL motifs could hinder the transcription process [16,17]. 


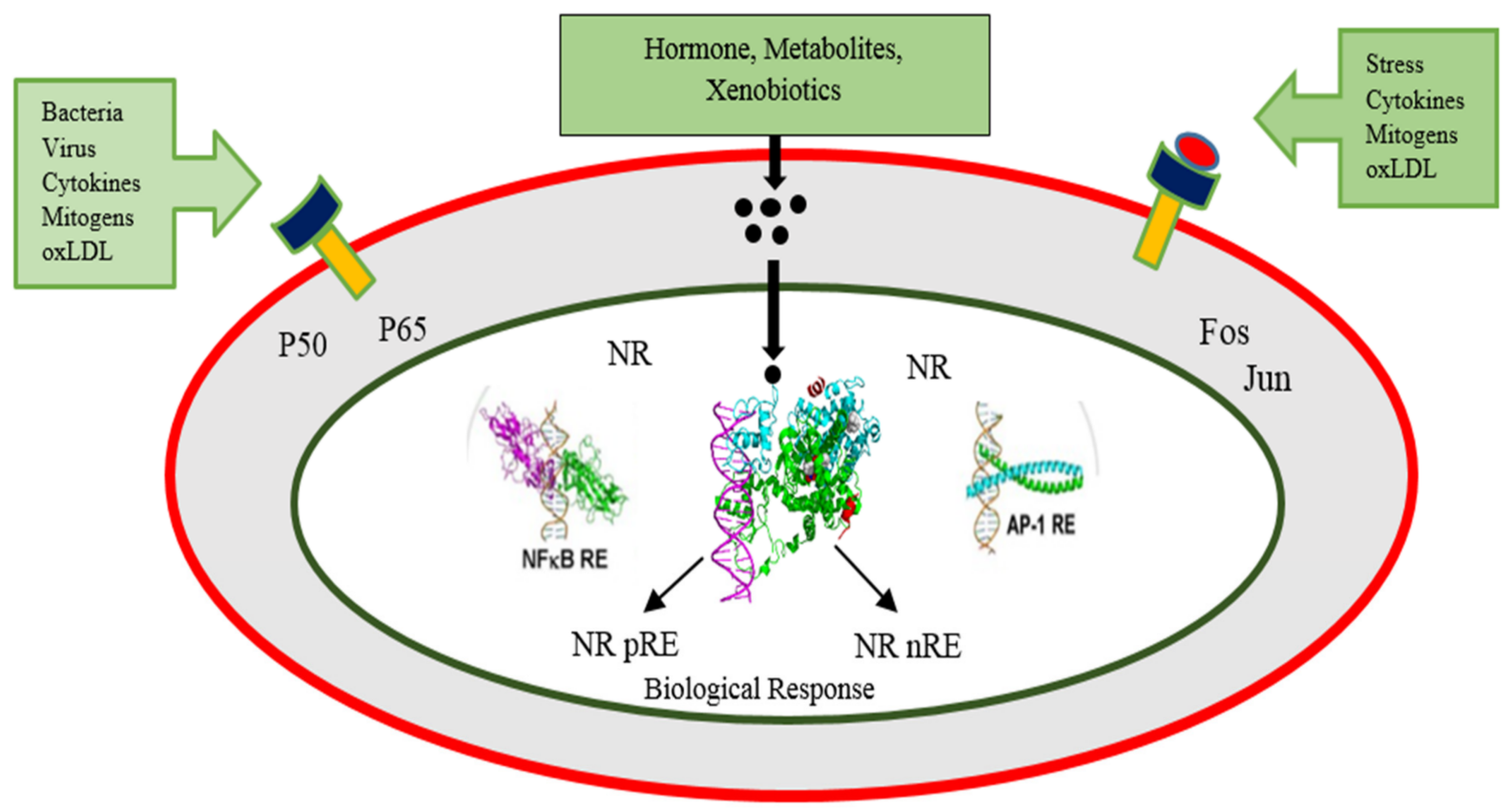

Figure 2. Nuclear receptors work in two apparent manners. Firstly, through the binding of a ligand, these receptors can frame, Heterodimers with RXR that outcomes in their connection with a specific positive response element of gene and, in this manner, can cause transcription of mRNA of genes that are targeted. On the other hand, repressive, negative response elements (nRE) have likewise been observed to interact with these receptors [9].

\subsection{Nuclear Receptor Corepressor Binding}

In the absence of ligands, the NRs are found to be associated with the corepressor complexes. These complexes consist of a subunit (SMRT/NcoR2 or NCoR1) that interacts directly with the receptor by means of the LXXLL motif that has a consensus sequence (L/I-X-X-I/V-I or LXXXI/LXXXI/L) also referred to as the CoRNR $[18,19]$. This CoRNR box motif interacts, as the coactivator LXXLL motif, with amino acids from the LBD hydrophobic groove. Part of the CoR binding interface is obscured as the remodeling of the binding of agonist and helix 12 positioning takes place. The availability of CoR binding interfaces as well as new CoRNR boxes indicates the use of alternate methods for the interaction of NR-corepressor [20-22]. The corepressor complexes are also developed around the NCoR or SMRT subunits that have a conserved repression domain and act as a vital point for core repressive machinery (such as GPS2, HDAC3, TBL1/TBLR1B) to assemble. Under certain situations, ligand-binding is adequate to prevent the recruitment of corepressors, such as RXR and TR, but in these cases, the active corepressor complex needs to be eliminated.

\subsection{Nuclear Receptor Coactivator Binding}

The identification of SRC-1/NCoA1 as a coactivator of the progesterone receptor [23] led to the discovery of more than 350 coactivators up to now. This tremendous volume of polypeptides had their involvement in different enzymatic processes related to the chromatin remodeling, histone modulation, transcription initiation and elongation, mRNA splicing and elongation and nuclear receptor complexes' proteasomal termination [24]. These coactivators are further categorized into two subfamilies. The members of the first subfamily of coactivators are involved in the direct interaction with NR AF- 1 and 2 regions such as SRC coactivators, CBP and p300. The members of second subfamily coactivators can interact with primary coactivators such as CoCoA, CARM1 and Fli-I. The primary and secondary activators work in a coordinated manner to regulate the promoters [25]. 
p160 and p300 Families

Coactivators such as P160, p300 and cAMP-response element-binding protein (CBP) belongs to the p160 family such as NCoA1/SRC-1 and NCoA2/TIF2, commonly referred as SCRP1 or GRIP1, and possess binding affinity with the LBD of NR by means of an Alpha-Helical LXXLL motif [26]. The p160 family coactivators include NCOA 1/SRC-1, NCOA 2/TIF2 (SRC-2 or GRIP1) and NCoA3/RAC3, also known as SRC-3, ACTR, PCIP or TRAM-1. The p300 and CBP coactivators have a histone acetylase transferase (HAT) function, which plays a crucial role in NR-mediated transcriptional regulation [27]. The acetylation of histone $\mathrm{H} 4 \mathrm{~N}$-terminal tail inhibits the interactions of the histone $\mathrm{H} 4 \mathrm{~N}$ terminal with the histone $\mathrm{H} 2 \mathrm{~A} / \mathrm{H} 2 \mathrm{~B}$ dimer and disrupts chromatin compaction [28]. Thus, the chromatin is then decondensed causing the initiation complex at the promoter site to be attached.

\subsection{Transcriptional Repression}

\subsubsection{Transcriptional Repression by Unliganded Receptors}

In the absence of a ligand, some nuclear receptors can effectively downregulate the transcription. Thus, corepressor complexes recruiting is linked to this process. The most widely studied complex is the nuclear receptor corepressor (NCoR) that acts as a silencing mediator of thyroid and retinoid receptors (SMRT), G-protein pathway suppressor 2 (GPS2), histone deacetylase 3 (HDAC3), TBL-1-like related protein (TBLR1) and transducin- $\alpha$-like 1 (TBL1). A well-characterized function of HDACs in transcriptional repression is to create a condensed, transcriptional inactive chromatin structure by the $\mathrm{N}$-terminal lysine of histone proteins deacetylation. The SMRT and NCoR have been reported to possess a deacetylase-activating domain which can activate the enzymatic activity of HDAC3 [29].

Moreover, some other corepressor complexes, such as the SWI/SNF complex, CoRest and PRC1 and 2 complexes, have been further identified. Similarly, the NCoR/SMRT complex can bind with multiprotein elements of the promoter's site, resulting in covalent histone and DNA changes, accompanied by chromatin contraction and/or DNA masking. The dissociation of the corepressor complex from the DNA-bound receptor is a key step in NR-mediated transcription activation. In vitro experiments along with the data from the crystal structures have shown that agonist-induced conformational changes are adequate for SMRT or NCoR alienation. However, dynamic models of de-repression involving post-translational modifications of corepressor complex subunits leading either to their nuclear exclusion and/or degradation have been described [30].

\subsubsection{Direct Trans-Repression by Ligand Activated Receptors}

The negative transcription regulation of certain genes can be repressed by ligandbounded NRs. The mechanistic role of these ligand-bounded NRs has already been described in-depth for the GRs and TRs. These NRs have been suggested to recognize, bind and downregulate particular target genes. Studies have shown that the response elements which negatively regulate the glucocorticoid or rnGREs and thyroid elements or nTREs differ from those of response elements that positively control the activation of transcription process [31,32]. The negative response elements for GR and TR possess the overlapping binding sites that control the response elements transcriptional cis-effect for transcriptional factors such as Oct-1/Pbx, AP-1 and SP1 [33-35]. This indicates that the negative glucocorticoid reaction elements associated with other transcription factors can exert such an action. A recent study has identified a new class of negative glucocorticoid REs, which are arranged as $1 \mathrm{bp}$ spacers inverted repeats and facilitate the glucocorticoids to promote the recruitment of GR-corepressor complexes [36]. For T3-mediated repression of transcription, a similar type of mechanistic principle does not exist. The SMRT corepressor insertion in nTRE enhances the histone deacetylation that has also been reported for the $\alpha \mathrm{TSH}$ gene. The SMRT dissociation is associated with histone acetylation and gene suppression after treatment with an agonist [32,37]. Additionally, functional studies have revealed the involvement of SRC-1 in liganded TR transcriptional repression [38,39]. 
The mechanism involved in the reversal of the transcriptional function is not clear yet, but it can be regulated by means of post-translation changes, including acetylation or SUMOylation of promoter-associated histones, phosphorylation and/coregulatory proteins $[24,40]$. Therefore, direct repression could happen through distinct receptors and context-dependent pathways. These findings also indicated the versatility of coregulator complexes that either positively or negatively impact the products of the transcription following the stimulation by NR agonists.

\subsubsection{Tethered Transrepression by Liganded Receptors}

The process called the tethered transrepression contains negative crosstalks of ligandactivated nuclear receptors with other signal-dependent transcription factors, including NF-kappa-B and AP-1. Inflammation in different cells of the central nervous system, the immune system and in the liver, etc., is modulated by this process and also interferes with cell proliferation in many tissues. Various putative mechanisms have also been proposed to explain such repression: (i) the inhibition of PIC assembly on NF-kappa- or AP-1-regulated promoters; (ii) the inhibition of RNA polymerase II change to elongation-competent form; (iii) the upregulation of NK-kappa-B inhibitors [41]; (v) the coactivators exclusion by competitive inhibition [42,43]; (vi) direct physical interaction with AP-1 or NF-kappa-B subunits (p65 commonly) [43], but this mechanism is even more complicated and intricate with several other factors in the cell [44].

Moreover, after being partly affected by PPAR $\gamma$, GR and LXR agonists, for each receptor, the inhibition was about one-third or half of the gene induced by TLR-3, 4 or 9 active macrophages inflammatory elements. Interestingly, each receptor was partly overlapping with inhibited clusters of genes [45].

The NR structural features unique to transrepression are not well described yet. Research using comprehensive mutagenesis of T3R, RAR, PPAR $\mu$, GR and ER has not provided a simple, harmonized model for tethered transrepression [46,47]. Thus, it is evident that the coactivators recruitment through the Domain AF-2, as well as direct DNA connections, is not necessary for this process. Furthermore, it also became apparent that homoor heterodimerization was not obligatory $[47,48]$. The unavailability of defined molecular structures for transrepression is the major hindrance in devising screening methods for the detection of dissociated ligands that preferentially induce tethered transrepression in inflammatory diseases.

\section{Role of PPARs and Coregulators in Energy Homeostasis}

Energy is an absolute necessity to provide subsistence to all the living beings and is usually derived from the metabolism of ingested nutrients. Primarily, in human beings, glucose and long-chain fatty acids derived from food are utilized to produce energy. The cellular requirement for energy is satisfied through the oxidation reactions occurring in mitochondria to metabolize nutrients. Both in normal as well as in induced cells, the transcriptional regulation network controls the demand and supply of diverse cellular physiological states in both normal and induced cells such as during fasting or exercise. PPARs are classified as a part of the superfamily of nuclear receptors within this transcriptional network and control the nutrient-dependent transcription [49-51]. PPARs function as fatty acid sensors in order to control various metabolic processes, and different biological activities such as inflammation, adipogenesis, insulin sensitivity, lipid metabolism, reproduction as well as cell growth and differentiation. PPARs control these functions through the activation of target genes via the attachment of endogenous ligands to the receptors' ligand-binding domain. This binding leads to conformational change, which further enables PPARs to heterodimerize the retinoid $X$ receptor and facilitate the attachment and dissociation of transcription-related important small accessory molecules. This heterodimerized complex formed at the PPAR response elements (PPREs) then transactivates target mitochondrial and peroxisome-related genes. This event cascade controls a protein network concerned with systemic energy homeostasis [51-53]. All the isotypes 
of PPARs have an indispensable role in lipid and fatty acid metabolism through direct binding or the modulation of the target genes related to fat metabolism [49]. Though all these PPAR isoforms share similar mode of action and function, distinct biological and pharmacological differences exist among them. The PPAR $\beta / \delta$ and PPAR $\alpha$ have a metabolic role in the promotion of energy dissipation, but PPAR $\gamma$ stimulates the energy storage. PPAR $\beta / \delta$ improves fatty acids oxidation in different body tissues and also normalizes plasma lipid content. PPAR $\beta / \delta$ and PPAR $\gamma$ boost insulin sensitivity, while PPAR $\alpha$ do not. $\operatorname{PPAR} \beta / \delta$-mediated glucose regulation is different from that of PPAR $\gamma$; however, PPAR $\beta / \delta$ and PPAR $\gamma$ both are implicated in fiber distribution in the skeletal muscle, metabolism of glucose in the liver and controlling pancreatic islet cells function [53]. In lipid catabolism, the PPAR $\alpha$ enhances the fatty acid oxidation during situations such as fasting, while PPAR $\gamma$ acts on the adipose tissue during the anabolic process to improve lipogenesis [54,55]. Thus, understanding the role of PPARs in energy homeostasis is important to further investigate the PPARs' role in producing energy in different body parts.

\subsection{The ATP-Dependent Remodeling Complex SWI/SNF}

In yeast, the SWI/SNF complex is an evolutionarily conserved multi-subunit complex, which uses the energy of ATP hydrolysis to mobilize nucleosomes and remodel chromatin and thereby regulate the transcription of target genes. In ATP-dependent chromatin restructuring [56], the evolutionary conserved SWI/SNF families play a significant role in catalyzing the DNA histone disruption and the nucleosome sliding around the DNA [57]. A multimeric agent of $1.2 \mathrm{MDa}$ is the human homolog BAF complex of BRG1/hBRM, BAF Polypeptides (BAF45a/b/c/d, BAF47, BAF53a/b, BAF57, BAF155/170, BAF60, BAF250a, BAF200, Brd7 and Brd9) and actin. A number of these subunits have LXXLL motifs which have not only been identified in the form of ER, RR [58], RAR [59], FXR [60] and GR [61] coactivators but also as SHP corepressors [62], which also incorporated with corepressor complexes in order to combine SWI/SNF components [63]. Intriguingly, in the mouse liver, the BAF 60a subunit showed a circadian expression, which regulates the expression of clock and metabolic genes by acting as a coregulator of ROR $\alpha$ [64].

\subsection{The Mediator Complexes}

The mediator complex was initially identified in yeast, such as the SWI/SNF complex, and consequently characterized in many other eukaryotic cells. Many studies have identified its role as a catalyst for the transcription pre-initiation complex, abbreviated as PIC, assembly of activated promoters. The mediator plays a major role in RNA II-controlled transcription mechanism by direct association with RNA polymerase II, such as TFIID and TFIIH, and elongation factors [65]. Different studies have reported the function of the mediator in NR and made it clear that complexes linked to mediators are specifically associated with NRs. The mediator consisted of four structural modules and had more than 20 subunits, among which LXXLL motifs [66] were developed from the Med1 subunit. The hepatic steatosis Med1 KO causes PPAR $\alpha$-dependent steatosis [67], in line with the coactivator functions of the liver [68] and PPAR $\alpha$ [69].

\subsection{PPARs Signaling in Different Body Parts}

The liver is the prime body organ involved in energy metabolism to fulfill the body's energy requirements, and PPAR $\alpha$ receptors are also distributed in the liver, which controls the uptake and breakdown of fatty acids through ketogenesis and $\beta$-oxidation in fasting conditions [70,71]. It has also been described that PPAR $\alpha$ knockout in mice causes the suppression of fatty acids uptake and oxidation and the impairment of ketogenesis as well as gluconeogenesis. Furthermore, the function related evidence for PPAR $\beta / \delta$ were also reported as the PPAR $\beta / \delta$ knockout decreases the expression of genes involved in glucose and lipogenesis, while PPAR $\beta / \delta$ overexpression controls genes that are responsible for energy metabolism [49]. In the liver, PPAR $\alpha$ is indispensable for glucose homeostasis. The mice deficient in PPAR $\alpha$ showed a substantial blood glucose level reduction following 
$24 \mathrm{~h}$ of fasting. The upregulated expression of TRB3 (a positive controller of the cellular reaction to the levels of insulin and Akt/protein kinase B blocker) directly regulates the $\operatorname{PPAR} \alpha$ transcription that negatively influences insulin signaling [72]. Moreover, PPAR $\alpha$ also enhances the production of acetyl-CoA enzyme and fatty acids oxidation through upregulating Acyl-CoA dehydrogenase expression in mitochondria. PPAR $\alpha$ controls de novo lipogenesis in the case of positive energy balance to provide fatty acids, deposited in the form of triglycerides, which can also be employed during starvation [73].

Brown adipose tissue (BAT) acts as a caloric storage site, and white adipose tissue (WAT) as lipid storage also holds importance in energy homeostasis. These tissues are involved in endocrinal functions, which also release different types of hormones, including adipokines and cytokines, which subsequently initiate systemic energy metabolism signaling. Through feedback mechanisms, these tissues control energy homeostasis by receiving signals from the metabolic active sites in peripheral tissues and the central nervous system [74-76]. Substantially, PPAR $\gamma$ is expressed in these tissues and plays a lead role in the gene activation required for the uptake and deposition of fatty acids as well as the differentiation of adipose tissue [77]. Non-adipogenic cells are differentiated into adipocytes through the ectopic expression of PPAR $\gamma$ [78]. The PPAR $\gamma$ knockout in embryonic fibroblasts completely disrupts the differentiation process [79]. In vivo studies have revealed the importance of PPAR $\gamma$ for adipocytes production and survival in animals as negative mutations (heterozygous and dominant) in the PPAR $\gamma$ in humans cause lipodystrophy $[15,80]$. In BAT, PPAR $\alpha$ controls the expression of mitochondrial uncoupling protein 1 (UCP1) and PGC $1 \alpha$, but the obliteration of PPAR $\alpha$ decreases the protein expression upon exposure to normal and cold conditions while the fatty acids' metabolism is not affected. The enhanced energy metabolism has also been observed in response to the enhanced expression of the FAO gene induced by the activation of PPAR $\alpha$ in human and murine adipocytes [49]. Liu et al. reported PPAR $\gamma$ as a positive regulator of milk fat synthesis in dairy cow mammary epithelial cells through improving cell viability, proliferation ability and triacylglycerol secretion [81]. It was also reported that acetic acid and palmitic acid could regulate milk fat synthesis in dairy cow mammary epithelial cells through PPAR $\gamma$ signaling. Shi et al. have cloned the PPAR $\gamma$ gene in the dairy goat mammary gland and explored its function in vitro [82]. It was reported that PPAR $\gamma$ in the goat mammary gland directly controls the synthesis of milk fat through the activation of the transcription regulators, such as sterol regulatory element-binding transcription factor-1 $[82,83]$.

Skeletal body muscles are the significant sites for glucose usage mediated through insulin, lipids metabolism, glycogen storage and oxidation of fatty acid as well as regulation of HDL and cholesterol levels. PPAR $\beta / \delta$ expression is dominant in the skeletal muscles and controls the translation of genes associated with energy metabolism [71,84-86]. Moreover, it also regulates the activity of genes related to triglyceride hydrolysis, lipids uptake, fatty acids oxidation, and uncoupling proteins activation to liberate the energy required by OXPHOS. The protein CPT1 is also programmed to regulate the oxidation of the long-chain fatty acids. PPAR $\beta$ / T activates the metabolic adaptability of the transcription factor FOXO1 and the pyruvate dehydrogenases kinase 4 (PDK4), which inhibits the complex of pyruvate dehydrogenase. This makes CPT1 a rate-limiting factor for the oxidation of carbohydrates in the muscles. Moreover, PDK4 also controls the regulation of several genes that are involved in lipid efflux, energy usage and increases $\beta$-oxidation of fatty acids [84,85]. Furthermore, in PPAR $\beta / \delta$ transgenic mice, metabolism of glucose was greatly amplified [84] as PPAR $\beta$ could initiate the transcription of lactate dehydrogenase B (LDHB) to regulate the muscle fatty acid metabolism required for glucose oxidation [87]. On the other hand, PPAR $\gamma$ coactivator- $1 \alpha$ or PGC- $1 \alpha$, which is a mitochondrial biogenesis regulator, controls the energy metabolism in skeletal muscle through catabolic reactions to produce aerobic ATP. The PPAR $\beta / \delta$ stimulates the expression of PGC- $1 \alpha$ to control the skeletal muscles' metabolic activity by enhancing the synthesis of mitochondrial proteins [88-90].

The PPAR $\alpha$ and PPAR $\beta / \delta$ are predominantly expressed in the intestines [91,92], and the triglycerides' metabolism in the intestine is crucial for systemic energy homeostasis. Di- 
etary triglycerides are hydrolyzed into free fatty acids in the intestinal lumen and then taken up by epithelial cells of the intestine to the endoplasmic reticulum and again converted into triglycerides [92]. Studies in animals have shown a relationship between energy utilization, intestinal colonization and weight gain that controls the angiopoietin-like protein 4 (ANGPTL4) expression in the intestinal epithelium. ANGPTL4 is a secreted protein that regulates lipid and glucose homeostasis, and its deletion leads to changes in metabolism, reduced oils absorption in the intestine and intestinal mucosa thickening. PPAR $\gamma$ is reported to be involved in the regulation of the fatty acid metabolism via $\beta$-oxidation. PPAR $\gamma$ controls ANGPTL4 expression, and short-chain fatty acids stimulate PPAR $\gamma$ and are the major energy resources for colonocytes [93]. Wy-14643 is a PPAR $\alpha$ agonist that stimulates the production of the enzymes implicated in fatty acid oxidation and ketogenesis, such as mitochondrial 3-hydroxy-3-methylglutaryl-CoA synthase and CPT1A in the small intestine [94]. PPAR $\alpha$ also controls different phase I enzymes and transporters (related to oxidation) as well as uptake of fatty acids. PPAR $\alpha$ is activated through the nutritional route and regulates fatty acid oxidation, cholesterol and glucose transporters [95]. PPAR $\alpha$ is crucially involved in the regulation of the phage I/II metabolism and also controls the expression of transporter genes in the small intestine [96]. A synthetic agonist (K-877) of PPAR $\alpha$ has been shown to control the intestinal fatty acid oxidation and mRNA expression of apo-lipoprotein while reducing plasma levels of triglycerides. The downregulation of Npc111 and upregulated expression of Abca1 has been observed in response to treatment with K-877. Npc111 is a rate-restricting transporter for absorption of cholesterol in the murine small intestine, while Abca1 is a vital molecule that participates in the production of HDL-C in the small intestine [97].

\subsection{Energy Homeostasis through Co-Regulators of PPARs}

The energy homeostasis could be controlled through feedback mechanisms involving various types of extraordinarily interconnected pathways. About 320 coregulators and 38 co-modulators for PPARs have been reported in the Nuclear Receptor Signaling Atlas. The direct interaction of PPARs and the crosstalk of PPARs with other pathways contribute to systemic energy homeostasis [98].

Balanced mitochondrial energy production is being regulated through the coordinated effect of coactivators and corepressors where PGC- $1 \alpha$ and PPAR $\gamma$ act as co-modulators for the initiation of mitochondrial aerobic metabolism. However, the effect of PGC1 $\alpha$ on mitochondria is antagonized via nuclear corepressor 1 (NCOR1). The knocking out of NCOR1 has been shown to imitate the overexpression of PGC- $1 \alpha$ phenotypically, which is involved in the transcriptional output of ERR and PPARs. Nuclear receptor interacting protein 1 (NRIP1) interacts with both PPARs and ERR and decreases the target gene expression levels that participate in the consumption of energy. In previous studies, the mice with the deletion of NIRP were slim and presented enhanced insulin sensitivity and glucose tolerance and endurance to diet-induced obesity $[50,98,99]$. Hes6 protein, hepatocyte nuclear factor $\alpha(\mathrm{HNF} \alpha)$ and the PPARs coregulate each other's expression under different nutritional conditions and also control the transcription events during the metabolic reactions $[80,100]$. $\operatorname{PPAR} \gamma$, along with the transcription factor such as CCAAT/enhancer-binding protein $\alpha$ $(\mathrm{C} / \mathrm{EBP} \alpha)$, is a crucial regulator in the last phase of adipogenesis. Energy homeostasis by the mediator complex subunit 1 (MED1) through PPARs plays an essential role in a liver-specific knockout of MED1 and demonstrated impaired activities of PPAR $\alpha$ and PPAR $\gamma$ in murine models [98].

Since the role of PPARs in different energy homeostasis cascades in various organs has been established, it can be stated that PPARs could be the target for the treatment of disorders, such as inflammation, obesity, diabetes, dyslipidemia, neurodegenerative disorders and cardiac myopathy, when these cascades are disrupted in disease conditions due to metabolic energy imbalance $[15,101]$. 


\section{Nutritional Modulation of PPARs to Modify Gene Expression and Metabolic Networks}

Dietary nutrients can modulate the metabolic networks of PPARs as nutrients, and their products directly control the PPAR activities through acting as natural ligands of PPARs. Diverse nutrients have been shown to affect the action of PPARs, but PPARs depict the greatest inclination for mono-unsaturated and poly-unsaturated fatty acids as demonstrated by different ligand-binding assays [102,103]. It is evident that each type of PPAR triggers a distinct gene network regardless of their overlapping expressions, which indicates the exhibition of ligand-specific properties of PPARs [103,104]. Furthermore, the administration of high-fat diet results in the modulation of PPAR $\alpha$ target genes [105]. Comparative nutrigenomic study in mice revealed the influence of several individual dietary fatty acids on hepatic gene expression. These findings concluded that (1) an increase in the chain length of fatty acids and the extent of unsaturation enhanced the total genes that were upregulated and that (2) genes controlled through dietary unsaturated fatty acids do not change in the PPAR $\alpha$ knockout murine model depicting PPAR $\alpha$ as end target, and the expression levels of same genes were increased in the murine model after the administration with the PPAR $\alpha$ activator WY14643 [106].

The modulation of PPAR expression and function through nutrients can be studied by imposing nutrient deprivation conditions on diverse tissues. The properties of all known PPARs are influenced in the fasting state; for example, PPAR $\alpha$ signaling in the liver has shown to be upregulated via fasting through increased expression levels of the coactivator PGC- $1 \alpha$, and thus controls hepatic gluconeogenesis and fatty acid oxidation $[107,108]$. Furthermore, increased expression levels of PPAR $\delta$ during fasting are affected by plasma fatty acids derived from adipose, hence highlighting a distinct task as a plasma fatty acid sensor in the liver for PPAR $[108]$.

Several nutrients and their derivatives are being observed for the modulation of PPARs to modify metabolic networks and gene expression through direct and indirect mechanisms. Macronutrients such as nucleotides, fatty acids and their metabolites, amino acids, monosaccharides and micronutrients, such as vitamins, can control the expression of specific genes directly by interacting with transcription factors in the promoter region through cis-regulatory elements. However, many nutrients regulate genes indirectly by modulating the intracellular action/secretion of hormones, such as thyroid hormone, glucocorticoids, glucagon and insulin, which alters the gene expression and thus improves metabolic networks. Many dietary nutrients have been shown to modulate the expression of PPARs in animals (Figure 3), among which some significant factors are described below.

\subsection{Poly Unsaturated Fatty Acids (PUFA)}

Polyunsaturated fatty acids are categorized as $n-3$ and $n-6$ fatty acids and could exert opposing effects on receptor signaling. Out of these two classes, $n-3$ fatty acids are shown to have an agonistic effect, while $n-6$ fatty acids are reported to be inhibitory [109]. PUFAs are shown to bind directly to the PPAR $\alpha$ and are involved in the activation of transcription, thus controlling metabolic networks. It has been reported that PUFAs are required in the $\mu \mathrm{M}$ range to bind with $\operatorname{PPAR} \alpha$, and these could be derived from dietary nutrients [110]. Interestingly, $n-3$ fatty acids are reported to be greater activators of PPAR $\alpha$ as compared to $n-6$ fatty acids in vivo [111]. Furthermore, many eicosanoids and their derivatives are shown to activate PPAR $\alpha$ with a high affinity than other PUFA precursors [112]. Studies have represented that acylethanolamines, including oleoylethanolamide (OEA), palmitoylethanolamide (PEA) and anandamide (AEA) are also PPAR $\alpha$ activators [113]. Moreover, PPAR $\alpha$ activation by oleoylethanolamide (OEA) leads to appetite and lipolysis suppression, while palmitoylethanolamide (PEA) exerts anti-inflammatory activity when activating the PPAR $\alpha$ [114]. The ligands for PPAR $\alpha$ are also known to bind PPAR $\beta / \delta$, but their activation is lower than the PPAR $\alpha$. PUFAs also serve as ligands for PPAR $\gamma$ and are involved in the activation of PPAR $\gamma$. For example, n-3 fatty acid activates the PPAR $\gamma$ and can result in the prevention of high-fat-diet-induced inflammation in adipose tissues [115]. Collectively, PUFAs are the natural ligands for all the subtypes of PPARs, but their subsequent activation 
potential varies. These molecules control the PPARs activity in the body and thus have a role in regulating metabolic networks. Although various studies have reported their mechanism of action to activate PPARs, further research is still needed to elucidate the mechanisms of PPARs activation and their distribution.

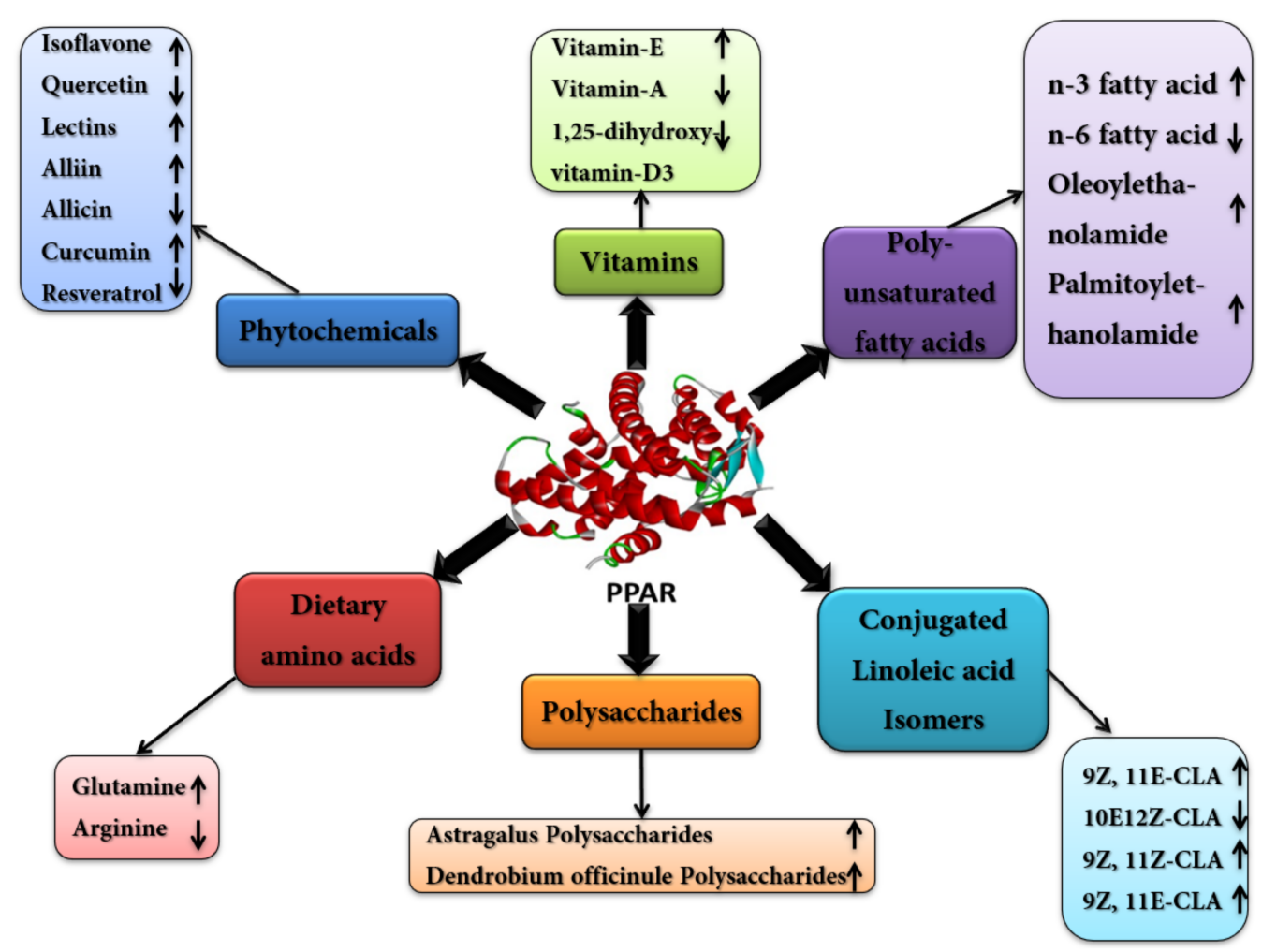

Figure 3. The effect of different nutrients on PPAR. Different nutrients regulate PPAR either by its upregulation or downregulation. The arrow up shows the upregulation of PPAR, while the arrow down shows the downregulation by respective nutrients.

\subsection{Conjugated Linoleic-Acids (CLAs)}

CLAs are the fatty acids mainly found in foods obtained from ruminant animals [116] and are positional (cis- or trans-double bond positioning at 7,$9 ; 8,10 ; 9,11 ; 10,12$; or 11, 13) and geometrical isomers of the parent linoleic acid molecule (cis-9, cis-12-18:2, n-6). Rumenic acid (9Z, 11E-octadecenoic acid, C18:2) is the most abundant natural CLA isomer (over $75-80 \%$ ) produced through the biohydrogenation of nutritive LAs by ruminant microflora. Because of their numerous health benefits, CLAs are currently being used as nutritional supplements for changing body composition in livestock and humans [117,118], but the mechanisms of the useful properties of CLAs are yet to be explored. CLA isomers serve as ligands for PPAR $\gamma$, PPAR $\beta / \delta$ and PPAR $\alpha[119,120]$, showing differential PPAR activation and health benefits [118,121] (Table 2).

Additionally, a mixture of CLA isomers, i.e., 9Z, 11Z-CLA and 9Z, 11E-CLA, can notably activate the PPAR $\beta / \delta$ in preadipocytes [122]. Therefore, minor structural changes in many CLA isomers can be differentiated by important cellular mechanisms to allow specie and tissue-specific responses [123]. These findings concluded that CLA affects the production of eicosanoids directly or indirectly, abolishes the NF- $\mathrm{kB}$ pathway, improvises the activation of PPAR $\gamma$ and decreases proinflammatory cytokines for useful effects on inflammation, ultimately manipulating metabolic syndrome-related conditions, including IR, atherosclerosis and obesity [124]. Therefore, CLAs can directly employ antiinflammatory properties by modulating the expression of inflammatory mediators through PPAR $\gamma$-dependent or NF-kB-dependent pathways. 


\subsection{Dietary Amino Acids}

Some of the dietary amino acids have shown the potential to modulate the activity of PPARs, in which glutamine and arginine are the major ones. Glutamine is considered an essential amino acid in situations of metabolic stress and is found to be a special substrate of enterocytes. To date, only a single study has reported the impact of glutamine on PPAR $\gamma$ articulation. Sato et al. examined the impacts of luminal glutamine and arginine on the activity of PPAR $\gamma$ in gut ischemia-reperfusion of a rat model. Luminal glutamine increased the expression of PPAR $\gamma$, while arginine did not show any significant effect on PPAR $\gamma$. Furthermore, they also evaluated the effect of a PPAR $\gamma$ antagonist (GW9662) on the action of glutamine. The pre-treatment with GW9662 revokes the impact of glutamine, revealing that glutamine may likewise be a PPAR $\gamma$ agonist, thus signifying its role in metabolic stress [125].

Moreover, the effect of arginine on a gut injury has been investigated, and the supplementation of arginine, which is considered an immune-nutrient, demonstrated a beneficial effect on LPS-induced gut injuries in a pig model [81]. Additionally, upon treatment with arginine, there was a decrease in jejunal TNFa, and an increase in the expression of PPAR $\gamma$ was also observed.

\subsection{Vitamins and Minerals}

\subsubsection{Beta Carotene, Vitamin A, and Its Derivatives}

In mammals, beta carotene (BC) is the precursor of apo-carotenoid molecules, i.e., retinoids (vitamin A and its derivatives) [126]. There is an increasing sign that BC and retinoids can affect the physiology of adipocytes as signaling molecules by acting on adiposity in humans [127]. The levels of circulating BC are inversely associated with the risk of human type-2 diabetes [128-130], while the decreased levels of plasma carotenoids, including BC, are usually found in obese children [131].

The $\mathrm{BC} 15,15^{\prime}$-monooxygenase ( $\mathrm{Bcmo1}$ ) is the major contributing enzyme for the production of retinoid, which converts $B C$ into all-trans-retinal [132]. Its expression is controlled by PPAR- $\gamma[133,134]$ induced during the differentiation of adipocyte [135], and Bcmo1 knockout mice showed an enhanced expression of PPAR- $\gamma$ genes in fat-deposits and are very susceptible to fat-induced obesity [132]. Retinaldehyde, the primary product of BC cleavage, inhibits the activity of PPAR- $\gamma$ both in mouse models and adipocyte cell cultures [136]. The role of $B c m o 1$ is verified in signaling of the RA receptor (RAR) and the production of Retinoic acid (RA) in adipocytes [135]. Furthermore, BC-derived long-chain apo-carotenoids, such as $\beta$-13-apocarotenone, proved to inhibit the activity of retinoid $X$ receptor-alpha $(\mathrm{RXR} \alpha)$, while $\beta$-apo-149-carotenal hinders the adipogenesis and activity of PPAR- $\gamma$ in cell culture [137]. BC supplementation can reduce the activity of PPAR- $\gamma$ and downregulate its target genes, decreasing the adiposity of mice. Thus, $\mathrm{BC}$ can significantly control the adiposity in mice, and Bcmol critically regulates the PPAR- $\gamma$, which is the key element for the connection between PPAR- $\gamma$ and RAR-signaling pathways that ultimately control the body adiposity [138].

\subsubsection{Vitamin E: Alpha Tocopherols and Tocotrienols}

Vitamin $\mathrm{E}$ is the fat-soluble vitamin family comprised of 8-lipophilic natural compounds including four tocotrienols with an unsaturated-isoprenoid sidechain designated as $\alpha, \beta, \gamma$, and $\delta$, and four tocopherols with a saturated phytyl-tail $[139,140]$. Soybean, cottonseed and corn are the commercially produced vegetable oils that have high amounts of most common dietary tocopherols ( $\alpha$ - and $\gamma$-tocopherols) [141,142]. Both $\alpha$ - and $\gamma$-tocopherol shown to activate expression of PPAR- $\gamma$ and transactivation of cancer cells in the colon, but $\alpha$-tocopherol modulate PPAR- $\gamma$ expression better than $\gamma$-tocopherol $[143,144]$.

Tocotrienols are non-toxic naturally occurring compounds used as dietary supplements to prevent damage with aging due to dysregulated inflammatory responses. Recently, in vivo anti-inflammatory properties of dietary supplements evaluated in mice and chickens with two natural proteasome-inhibitors, i.e., $\delta$-tocotrienol and quercetin $[145,146]$, 
revealed decreased levels of nitric oxide [147] and serum tumor necrosis factor-alpha $(\mathrm{TNF}-\alpha)$. Furthermore, the direct effect of tocotrienols on lipidic metabolism, with an anti-atherogenic effect on rats, humans and mice, has been also reported.

In vitro studies revealed that tocotrienols inhibit the 3-hydroxy-3-methyl-glutarylCoA reductase and consequently decrease cholesterol synthesis. For instance, the body fats in rats were decreased by the oral administration of a tocotrienol-rich fraction (TRF) of palm oil containing $\gamma$-tocotrienol, while in an in vitro study, the phosphorylation of Akt in 3T3-L1 preadipocytes and adipocyte differentiation was suppressed by TRF through the reduced expression of insulin-induced PPAR- $\gamma$ [148]. Tocotrienol can serve as an antiadipogenic vitamin due to nutrient-mediated regulation of body fat, but further research is required in this regard.

\subsubsection{Retinoic Acid and 1,25-Dihydroxy Vitamin D3 $\left(1,25(\mathrm{OH})_{2} \mathrm{D}_{3}\right)$}

Some of the properties of RA, such as the deposition of fats [149], adipocyte differentiation $[150,151]$ and the expression of adipokines, such as resistin, leptin and serum retinol binding protein, is facilitated by RAR, which interferes with the activity of PPAR$\gamma$ [149,151]. The 1,25-dihydroxy vitamin D3 $(1,25(\mathrm{OH}) 2 \mathrm{D} 3)$ is an active form of vitamin $\mathrm{D}$ and has been shown to restrict the adipogenesis in the bone marrow of SAM-P/ 6 mice associated with decreased expression of PPAR- $\gamma 2$ [152]. The suppressed expression of PPAR- $\gamma 2$ by RA and 1,25-dihydroxy vitamin D3 inhibit the differentiation of adipocytes in 3T3-L1 preadipocytes [153].

Table 2. Effect of different nutrients on PPARs modulation.

\begin{tabular}{|c|c|c|}
\hline Nutrients & PPARs Regulation & References \\
\hline \multicolumn{3}{|l|}{ Polyunsaturated fatty acids (PUFA) } \\
\hline n-3 fatty acids & $\begin{array}{l}\text { Activate both PPAR } \alpha \text { and PPAR } \gamma \text { and lead to } \\
\text { prevention of inflammation in adipocytes }\end{array}$ & {$[109,115]$} \\
\hline n-6 fatty acid & $\begin{array}{l}\text { Inhibitors of PPAR receptor signalling and regulate } \\
\text { metabolic network }\end{array}$ & [109] \\
\hline Oleoylethanolamide & Activate PPAR $\alpha$ and induce lipolysis & [114] \\
\hline Palmitoylethanolamide & $\begin{array}{l}\text { Activate PPAR } \alpha \text { and provide } \\
\text { anti-inflammatory activity }\end{array}$ & [114] \\
\hline \multicolumn{3}{|l|}{ Conjugated Linoleic acid (CLA) Isomers } \\
\hline 9Z, 11E-CLA & $\begin{array}{l}\text { Enhance PPAR- } \gamma \text { activation and exerts strong } \\
\text { anti-cancer effects }\end{array}$ & {$[119,154]$} \\
\hline 10E, 12Z-CLA & $\begin{array}{l}\text { Inhibits the PPAR- } \gamma \text { activation causing inflammation, } \\
\text { IR and adipocyte delipidation }\end{array}$ & [155] \\
\hline 9Z, 11Z-CLA and 9Z, 11E-CLA & Enhanced activation of PPAR $\beta / \delta$ in preadipocytes & [122] \\
\hline \multicolumn{3}{|l|}{ Dietary Amino acids } \\
\hline Glutamine & $\begin{array}{l}\text { Increase the expression of PPAR } \gamma \text { and prevent } \\
\text { metabolic stress }\end{array}$ & [125] \\
\hline Arginine & $\begin{array}{l}\text { Decrease the jejunal TNFa and increase the expression } \\
\text { of PPAR } \gamma \text { and beneficial against gut injury }\end{array}$ & [81] \\
\hline \multicolumn{3}{|l|}{ Vitamins } \\
\hline Vitamin-A [Beta Carotene (BC)] & BC supplementation can reduce the activity of PPAR- $\gamma$ & [138] \\
\hline Vitamin- E (Tocopherols) & $\begin{array}{c}\alpha \text {-tocopherol modulate PPAR- } \gamma \text { expression better } \\
\text { than } \gamma \text {-tocopherol }\end{array}$ & {$[143,144]$} \\
\hline 1,25-dihydroxy vitamin-D3 & $\begin{array}{l}\text { Decrease the expression of PPAR- } \gamma 2 \text { and regulate } \\
\text { lipid metabolism }\end{array}$ & [152] \\
\hline
\end{tabular}


Table 2. Cont.

\begin{tabular}{|c|c|c|}
\hline Nutrients & PPARs Regulation & References \\
\hline \multicolumn{3}{|l|}{ Phytochemicals } \\
\hline Isoflavone & Act as a ligand for PPAR to regulate lipid metabolism & [156] \\
\hline Quercetin & $\begin{array}{l}\text { Inhibits the activity of all isoform of PPARs except that } \\
\text { of PPAR- } \gamma \text { and prevent accumulation of fat in the liver }\end{array}$ & [119] \\
\hline Lectins & $\begin{array}{l}\text { Up-regulate the PPAR- } \gamma 2 \text { and provide an adipogenic } \\
\text { effect on mesenchymal cells }\end{array}$ & [155] \\
\hline Alliin & $\begin{array}{l}\text { Activates the PPAR- } \gamma \text { and provides a } \\
\text { cardioprotective effect }\end{array}$ & [157] \\
\hline Allicin & $\begin{array}{l}\text { Inhibit the PPAR- } \gamma 2 \text { and therefore inhibits the } \\
\text { differentiation and inflammation of the } \\
\text { human preadipocytes }\end{array}$ & [158] \\
\hline Curcumin & $\begin{array}{l}\text { Activates the PPAR- } \gamma \text { and confer antioxidant and } \\
\text { anti-inflammatory activity }\end{array}$ & [159] \\
\hline Resveratrol & $\begin{array}{c}\text { Down-regulate PPAR- } \gamma 1-3 \text { mRNA expression in } \\
\text { humans and provide anti-diabetic and } \\
\text { anti-obesity effects }\end{array}$ & [160] \\
\hline Triterpenes & $\begin{array}{c}\text { Suppress PPAR- } \gamma \text { expression and prevent } \\
\text { cancer development }\end{array}$ & [161] \\
\hline Polysaccharides & $\begin{array}{l}\text { Suppress PPAR- } \gamma \text { expression and exert } \\
\text { anti-cancerous activity }\end{array}$ & [161] \\
\hline
\end{tabular}

\subsection{Phytochemicals}

Plants possess biological active chemical compounds that are known as phytochemicals [162]. Importantly, flavonoids, lectins, alliin, allicin, curcumin, triterpenes and resveratrol have been observed to regulate lipid and glucose metabolism through the modulation of PPAR [127].

A soy isoflavone, genistein, regulates lipid metabolism by activating the PPAR- $\gamma$ or PPAR- $\gamma$-independent mechanism [156]. On the contrary, quercetin is a flavonol that inhibits the activity of all isoforms of PPAR except PPAR- $\gamma$ and prevents fat accumulation in the liver [119]. In literature, chicken feed supplemented with quercetin has prevented dysregulation of inflammatory responses by downregulating NO and TNF- $\alpha$ during aging, while isoflavones have the potential to induce cancer via hormone-dependent regulation [154].

The bioactivity of lectins from vegan sources has been reported several times related to immune responses or gastrointestinal tract during allergens exposure. Moreover, its adipogenic effect has also been reported in humans and animal tissues [155]. Banana, garlic and dietary lectins boosted the hematopoietic stem progenitor cell pool in addition to an adipogenic effect on mesenchymal cells of mice by enhancing PPAR- $\gamma 2$ expression. Furthermore, these dietary lectins interact with insulin receptors and activate the Mitogenactivated protein kinase (MEK)-dependent Extracellular signal-regulated kinase (ERK) pathway [163].

For more than 5000 years, garlic has been used as a culinary spice and medicinal herb. It has abundant antioxidant and organosulfur compounds that impart antibacterial and anti-infectious properties to it. Alliin and allicin are organosulfurated compounds extracted from garlic that possess a cardioprotective effect and anti-inflammatory effect, respectively [157]. Alliin lowers the TNF- $\alpha$ serum level in humans while allicin lowers or inhibits the expression of the CCAAT-enhancer-binding protein, CCAAT-enhancer-binding protein-alpha (C/EBP)- $\alpha$ and PPAR- $\gamma 2$ during human preadipocytes differentiation [158].

Curcumin is the principal component of turmeric with potent anti-inflammatory, anti-cancerous, and antioxidant activities. Curcumin can suppress sepsis through PPAR$\gamma$ and decrease IFN- $\gamma$ production in primed lymphocytes and iNOS gene expression in 
infected macrophages [159]. On the other hand, resveratrol, which has strong antioxidant properties, along with anti-obesity, anti-carcinogenic, neuroprotective, anti-aging, antidiabetic and analgesic activity, targets PPAR- $\gamma$ [164]. Resveratrol modulates white adiposetissue metabolism and prevents dysregulation of advanced glycosylation end-products (AGE) via PPAR- $\gamma$ mediated suppression of receptor for AGE in macrophage. It upregulates SIRT1, FOXO1 and adiponectin and downregulates PPAR- $\gamma 1-3$ mRNA expression in human visceral adipocytes [160].

Polysaccharides and triterpenes have been used as a treatment for atherosclerosis and inhibit invasive behavior, angiogenesis and proliferation in cancer models. Moreover, they significantly promote adiponectin production and adipocyte differentiation by the downregulation of PPAR- $\gamma$, SREBP-1c and C/EBP and suppress the expression of genes involved in lipid transport, synthesis and storage [161].

\section{Biological Benefits of PPARs Modulation in Dairy Animals}

Overall, the comparison of the function of PPARs in humans, mice and ruminants has revealed that PPAR isotypes have a similar role in the metabolism of lipids in different species, including dairy animals. However, some differences are found in their specific roles across species as PPARs are found to be more specific for unsaturated FAs in monogastric species, while in ruminants, the PPARs are more specific for saturated long-chain FAs [165]. Aside from their role in the metabolism of lipids, the PPARs also influence immune responses through the modulation of immune signaling pathways such as AP-1, STAT-1 and NFkb through protein-protein DNA-independent interactions, a greater yield of milk production and controlling metabolic stress in dairy animals [166].

\subsection{Energy Metabolism and Lipid Oxidation in Various Organs}

PPAR $\alpha$ is known to have an important role in fatty acid catabolism in mitochondria, peroxisomes and microsomes in the liver. PPARs are also believed to have a role in maintaining energy balance in various animals, such as ruminants and goats. Among its energy metabolism roles, carnitine homeostasis is well established in a diverse range of mammalian species, such as chicken, humans, mice, pigs, rats and diary animals [165]. Aside from PPAR $\alpha$, a few studies on the role of PPAR $\beta / \delta$ in energy metabolism have also been conducted. However, one role that is continuously associated with it is lipid metabolism. In the mammalian skeletal and heart muscles, the PPAR $\beta / \delta$ regulates fatty acid catabolism. These PPAR isotypes have also been found to have a crucial role in all of the reproductive tissues that have been investigated so far. In addition to this, research shows that PPAR $\beta / \delta$ has an important function in the metabolism of lipids in goat mammary cells, specifically lipid oxidation and secretion [83].

\subsection{Adipogenesis and Milk Production}

In ovines and bovines, PPAR $\gamma$ performs a critical role in adipogenesis, and its expression in the adipose tissues of these animals is high. PPAR $\gamma$ appears to be the critical mediator of lipogenesis by reacting quickly to stimuli signals in response to dietary energy intake [165]. For adipogenesis, PPAR $\gamma$ expression is both a requirement and a necessity. In bovines, PPAR $\gamma$ activation in bovine adipose tissue results in the upregulation of the genes that permit pre-adipocytes to differentiate into mature adipocytes or cells capable of storing triacylglycerol (TAG). One of the significant roles it plays in dairy animals from an economic benefit point of view is controlling the synthesis of milk fat in bovines. The PPAR expression increases during the transition state, which prevents the animal from metabolic stress [167]. The PPAR $\gamma$ gene is conserved in bovines, goats, humans and mice, as revealed by homology alignments. The research by Shi et al. confirmed the importance of PPAR $\gamma$ in modulating milk fat production. These findings showed that PPAR $\gamma$ is involved in regulating TAG production and release in the mammary cells of goats, highlighting the PPAR $\gamma^{\prime} \mathrm{s}$ functional significance of milk production in mammary cells. PPAR $\gamma$ affects the expression of genes involved in the regulation of milk fat in primary goat mammary epithelial cells as 
revealed by using a combination of experimental approaches, including gene expression analysis, PPAR $\gamma$-specific activation, luciferase-PPRE tests and siRNA interference [82].

\subsection{Controlling Inflammation}

In dairy animals, PPARs activation is also associated with anti-inflammatory effects in dairy cows during their transition period [168]. A Japanese group showed for the first time that PPAR $\gamma$ could perform an anti-inflammatory effect in dairy animals by injecting human recombinant TNF with agonist Thiazolidinedione TZD into dairy steers for 9 days. They discovered that TZD therapy partially restored TNF-induced insulin resistance [169]. The TZD impact was most likely due to increased insulin signaling via PPARs activation, which also counteracted TNF [170]. In dairy animals, the antiinflammatory impact of PPAR is evoked not just by mitigating the effects of TNF but also by lowering TNF synthesis. Bovine peripheral blood mononuclear cells treated in vitro with $100 \mathrm{M}$ of conjugated linoleic acid isomer (t10, c12-CLA) inhibited the TNF production, thus controlling the inflammation and overexpression of pro-inflammatory cytokines [171]. These pieces of evidence highlight the importance of PPARs modulated through their agonists and antagonists to control inflammatory stress in dairy animals and can be further used as targets to reduce metabolic stresses.

\subsection{PPARs and Fatty Liver Syndrome of Dairy Animals}

Since PPARs bind to and are activated by long-chain fatty acids and their metabolites, the PPARs play an extremely important role in nutrient metabolism. Due to the industrialization of the dairy industry and extensive farming that aims to maximize profits from each dairy animal, milk and meat production of dairy animals, such as cattle and bovines, has increased. Among many factors, one such factor is the use of energy-rich diets containing high amounts of carbohydrates and lipids. However, the intake of such high caloric diets in combination with the sedentary rearing system in the industrial farms, diseases such as non-alcoholic fatty liver (NAFLD) have become common, which has substantially increased the morbidity and mortality rates of these animals around the world. Among various NAFLD conditions, fatty liver syndrome constitutes one of the most common disorders that affect dairy cows and buffaloes during the perinatal period, and it is triggered by a negative nutritional balance following calving. Dairy cows are a good model for studying pathologies such as fatty liver syndrome and various other NAFLD types and their etiology [172]. A recent piece of research revealed that fatty liver disease in dairy cows during early lactation is linked to poor hepatic mitochondrial activity (like abnormal acetylation of amino acid lysine). PPAR $\gamma$ has a role in NAFLD through regulation of glucose and lipid metabolism and differentiation of adipocytes as well as modulation of inflammatory responses in the liver. PPAR $\gamma$ controls the expression of various target genes in adipocytes, participates in the adipocyte differentiation, influences lipid metabolism and principally controls signal transduction in the pancreatic islet cells, all of which contribute to the onset and progression of NAFLD. PPAR $\gamma$ is important in modulating lipid oxidation and lipogenesis, in addition to its role in adipocyte development [173].

\subsection{PPARs Interaction with Gut Microbiome and Animal Health}

There is a dearth of information related to the role of PPARs and gut microbiome in dairy animals and how their dysregulation leads to various pathologies related to metabolic stress. A recent review by Hassan et al. has provided interesting information regarding the interaction between gut microbiome and PPARs and their overall effect on the health of humans. As high-calorie diets containing high carbohydrates diminish good bacteria that aid in metabolizing various nutrients, low-energy diets containing high fiber do the opposite. It increases the population of certain bacteria such as Bifidobacterium, Lactococcus and Streptococcus that have been shown to alleviate fatty liver syndrome. This is attributed to the increase in the population of folate-producing bacteria whose metabolic product, folate, induces PPAR $\alpha$, which is involved in lipid oxidation in the liver [174]. Since isotypes 
such as PPAR $\gamma$ are highly conserved among mammals, some of the information should be implicated in dairy animals to improve their economic output and health.

One of the effects of high-calorie diets in all mammals is the modulation of gut microbiota. High-calorie intake is thought to affect gut microbial balance via the TLR4PPAR pathway. This can lead to (1) a rise in the number of microorganisms that produce inflammasomes (lipopolysaccharides) and (2) a reduction in the short-chain FAs. As a result, systemic inflammation rises, whereas the synthesis of short-chain FAs falls. Short-chain FAs activate PPARs in adipose tissue to control lipolytic genes, such as adipose triglyceride lipase and hormone-sensitive lipase, as well as lipogenic genes such as glycerol kinase and phosphoenolpyruvate carboxykinase, which aid in the appropriate metabolization and utilization of lipids. PPARs activity, on the other hand, declines as a result of a shortage of short-chain fatty acids, resulting in the formation of extra fat and subsequently its storage and increased inflammation [175].

\subsection{Other Benefits}

Extra-hepatic signals, including hepatokines such as fibroblast growth factor 21 (FGF21) and angiopoietin-like 4 (ANGPTL4) [176,177], have been described in monogastrics as PPARs targets that perform a key role in bovines related to the adaptation of tissues to low-energy state levels of the body, such as undernutrition, fasting and transition to lactation $[178,179]$.

The downregulation of the glucose transport mechanism in the bovine endothelial cells caused by excessive glucose has been also shown to be regulated by PPAR/ $\delta$ [180]. It has been previously demonstrated that activated PPAR $\delta$ suppresses the solute carrier family 2 member 1 (or facilitated glucose transporter GLUT1) expression while, at the same time, increasing the calreticulin expression, a protein that promotes GLUT1 mRNA degradation. Given the low levels of circulating glucose in ruminants $(<4 \mathrm{mM}$ in dairy cows) [181] against ca. $5 \mathrm{mM}$ in humans and $>6 \mathrm{mM}$ in mice), the condition investigated in the study (high glucose) has presumably minimal significance for ruminants. However, GLUT1 is among the most significant glucose transporters whose expression rises dramatically during the lactation period in mammary tissue of dairy cows [182]. Moreover, the modulation of glucose transport by PPAR $\beta / \delta$ might have ramifications in milk synthesis. As a result, these PPARs isotypes could be crucial in providing glucose for lactose production. Moreover, PPAR $\beta / \delta$ expression is significantly decreased in the mammary glands during lactation [183], which coincides with an upsurge in the expression of numerous glucose transporters, particularly GLUT1. If it is true, it opens up the possibility of employing PPAR $\beta / \delta$ antagonists to boost milk production.

Since PPARs have been identified as promising targets for improving metabolism and general wellbeing through nutritional interventions and various agonists and antagonists, further investigations are essentially required to provide physiological insights into the therapeutic role of PPARs in addressing various metabolic disorders in dairy animals.

\section{Conclusions}

PPARs are considered to be major nuclear receptors to control energy homeostasis in the body through various mechanisms in different body parts. Various nutrients can act as a ligand for PPARs for their modulation, in which PUFAs, dietary amino acids, vitamins and phytochemicals are the major ones. These nutrients modulate PPARs by regulating their expression and signaling in different body parts and lead to the control of metabolic networks.

Author Contributions: Conceptualization, S.u.R., Z.L. and K.C.; material searching, F.-u.H., A.N., M.J. and Q.L.; resources, S.u.R., Q.L., Z.L. and K.C.; writing-original draft preparation, F.-u.H. and A.N.; writing—review and editing, F.-u.H., A.N., M.J., S.u.R., J.A., M.S.-u.R., Q.L., Z.L. and K.C. All authors have read and agreed to the published version of the manuscript. 
Funding: The present study was supported by the National Natural Science Fund (U20A2051, 31760648 and 31860638), Guangxi Distinguished scholars Program (201835) and Guangxi University Post-doctorate Fellowship Research Grant (A3130051019).

Institutional Review Board Statement: Not applicable.

Informed Consent Statement: Not applicable.

Data Availability Statement: Not applicable.

Conflicts of Interest: The authors declare no conflict of interest.

\section{References}

1. Trevisi, E.; Amadori, M.; Archetti, I.; Lacetera, N.; Bertoni, G. Inflammatory response and acute phase proteins in the transition period of high-yielding dairy cows. Acute Phase Proteins Early Non-Specif. Biomark. Hum. Vet. Dis. 2011, 15, 355-379.

2. Sordillo, L.M.; Contreras, G.; Aitken, S.L. Metabolic factors affecting the inflammatory response of periparturient dairy cows. Anim. Health Res. Rev. 2009, 10, 53-63. [CrossRef] [PubMed]

3. Cai, D.; Liu, H.; Zhao, R. Nuclear Receptors in Hepatic Glucose and Lipid Metabolism During Neonatal and Adult Life. Curr. Protein Pept. Sci. 2017, 18, 548-561. [CrossRef] [PubMed]

4. Mangelsdorf, D.J.; Thummel, C.; Beato, M.; Herrlich, P.; Schütz, G.; Umesono, K.; Blumberg, B.; Kastner, P.; Mark, M.; Chambon, P. The nuclear receptor superfamily: The second decade. Cell 1995, 83, 835. [CrossRef]

5. Wu, Q.; Chambliss, K.; Umetani, M.; Mineo, C.; Shaul, P.W. Non-nuclear estrogen receptor signaling in the endothelium. J. Biol. Chem. 2011, 286, 14737-14743. [CrossRef]

6. Sun, Z.; Xu, Y. Nuclear receptor coactivators (NCOAs) and corepressors (NCORs) in the brain. Endocrinology 2020, 161 , bqaa083. [CrossRef]

7. Burris, T.P.; Busby, S.A.; Griffin, P.R. Targeting orphan nuclear receptors for treatment of metabolic diseases and autoimmunity. Chem. Biol. 2012, 19, 51-59. [CrossRef]

8. Sever, R.; Glass, C.K. Signaling by nuclear receptors. Cold Spring Harb. Perspect. Biol. 2013, 5, a016709. [CrossRef]

9. Pawlak, M.; Lefebvre, P.; Staels, B. General molecular biology and architecture of nuclear receptors. Curr. Top. Med. Chem. 2012, 12, 486-504. [CrossRef]

10. Dreyer, C.; Krey, G.; Keller, H.; Givel, F.; Helftenbein, G.; Wahli, W. Control of the peroxisomal $\beta$-oxidation pathway by a novel family of nuclear hormone receptors. Cell 1992, 68, 879-887. [CrossRef]

11. Issemann, I.; Green, S. Activation of a member of the steroid hormone receptor superfamily by peroxisome proliferators. Nature 1990, 347, 645-650. [CrossRef]

12. Waku, T.; Shiraki, T.; Oyama, T.; Fujimoto, Y.; Maebara, K.; Kamiya, N.; Jingami, H.; Morikawa, K. Structural insight into PPAR $\gamma$ activation through covalent modification with endogenous fatty acids. J. Mol. Biol. 2009, 385, 188-199. [CrossRef]

13. Forman, B.M.; Chen, J.; Evans, R.M. The Peroxisome Proliferator-activated Receptors: Ligands and Activators a. Ann. N. Y. Acad. Sci. 1996, 804, 266-275. [CrossRef]

14. Bionaz, M.; Chen, S.; Khan, M.J.; Loor, J.J. Functional role of PPARs in ruminants: Potential targets for fine-tuning metabolism during growth and lactation. PPAR Res. 2013, 2013, 684159. [CrossRef]

15. Wang, Y.-X. PPARs: Diverse regulators in energy metabolism and metabolic diseases. Cell Res. 2010, 20, 124-137. [CrossRef]

16. Lee, C.-H.; Chinpaisal, C.; Wei, L.-N. Cloning and characterization of mouse RIP140, a corepressor for nuclear orphan receptor TR2. Mol. Cell. Biol. 1998, 18, 6745-6755. [CrossRef]

17. Fernandes, I.; Bastien, Y.; Wai, T.; Nygard, K.; Lin, R.; Cormier, O.; Lee, H.S.; Eng, F.; Bertos, N.R.; Pelletier, N. Ligand-dependent nuclear receptor corepressor LCoR functions by histone deacetylase-dependent and-independent mechanisms. Mol. Cell 2003, 11, 139-150. [CrossRef]

18. Hu, X.; Li, Y.; Lazar, M.A. Determinants of CoRNR-dependent repression complex assembly on nuclear hormone receptors. Mol. Cell. Biol. 2001, 21, 1747-1758. [CrossRef]

19. Hu, X.; Lazar, M.A. The CoRNR motif controls the recruitment of corepressors by nuclear hormone receptors. Nature 1999, 402, 93-96. [CrossRef]

20. Varlakhanova, N.; Snyder, C.; Jose, S.; Hahm, J.B.; Privalsky, M.L. Estrogen receptors recruit SMRT and N-CoR corepressors through newly recognized contacts between the corepressor $\mathrm{N}$ terminus and the receptor DNA binding domain. Mol. Cell. Biol. 2010, 30, 1434-1445. [CrossRef]

21. Le Maire, A.; Teyssier, C.; Erb, C.; Grimaldi, M.; Alvarez, S.; De Lera, A.R.; Balaguer, P.; Gronemeyer, H.; Royer, C.A.; Germain, P. A unique secondary-structure switch controls constitutive gene repression by retinoic acid receptor. Nat. Struct. Mol. Biol. 2010, 17, 801-807. [CrossRef] [PubMed]

22. Phelan, C.A.; Gampe, R.T., Jr.; Lambert, M.H.; Parks, D.J.; Montana, V.; Bynum, J.; Broderick, T.M.; Hu, X.; Williams, S.P.; Nolte, R.T. Structure of Rev-erb $\alpha$ bound to N-CoR reveals a unique mechanism of nuclear receptor-co-repressor interaction. Nat. Struct. Mol. Biol. 2010, 17, 808. [CrossRef] [PubMed]

23. Onate, S.A.; Tsai, S.Y.; Tsai, M.-J.; O’Malley, B.W. Sequence and characterization of a coactivator for the steroid hormone receptor superfamily. Science 1995, 270, 1354-1357. [CrossRef] [PubMed] 
24. Han, S.J.; Lonard, D.M.; O'Malley, B.W. Multi-modulation of nuclear receptor coactivators through posttranslational modifications. Trends Endocrinol. Metab. 2009, 20, 8-15. [CrossRef] [PubMed]

25. Dasgupta, S.; Lonard, D.M.; O'Malley, B.W. Nuclear receptor coactivators: Master regulators of human health and disease. Annu. Rev. Med. 2014, 65, 279-292. [CrossRef]

26. Chen, D.; Huang, S.-M.; Stallcup, M.R. Synergistic, p160 coactivator-dependent enhancement of estrogen receptor function by CARM1 and p300. J. Biol. Chem. 2000, 275, 40810-40816. [CrossRef]

27. Roth, S.Y.; Denu, J.M.; Allis, C.D. Histone acetyltransferases. Annu. Rev. Biochem. 2001, 70, 81-120. [CrossRef]

28. Luger, K.; Mäder, A.W.; Richmond, R.K.; Sargent, D.F.; Richmond, T.J. Crystal structure of the nucleosome core particle at $2.8 \AA$ resolution. Nature 1997, 389, 251-260. [CrossRef]

29. Li, J.; Wang, J.; Wang, J.; Nawaz, Z.; Liu, J.M.; Qin, J.; Wong, J. Both corepressor proteins SMRT and N-CoR exist in large protein complexes containing HDAC3. EMBO J. 2000, 19, 4342-4350. [CrossRef]

30. Perissi, V.; Jepsen, K.; Glass, C.K.; Rosenfeld, M.G. Deconstructing repression: Evolving models of co-repressor action. Nat. Rev. Genet. 2010, 11, 109-123. [CrossRef]

31. Sakai, D.D.; Helms, S.; Carlstedt-Duke, J.; Gustafsson, J.-A.; Rottman, F.M.; Yamamoto, K.R. Hormone-mediated repression: A negative glucocorticoid response element from the bovine prolactin gene. Genes Dev. 1988, 2, 1144-1154. [CrossRef]

32. Chatterjee, V.; Lee, J.-K.; Rentoumis, A.; Jameson, J.L. Negative regulation of the thyroid-stimulating hormone alpha gene by thyroid hormone: Receptor interaction adjacent to the TATA box. Proc. Natl. Acad. Sci. USA 1989, 86, 9114-9118. [CrossRef]

33. Diamond, M.I.; Miner, J.N.; Yoshinaga, S.K.; Yamamoto, K.R. Transcription factor interactions: Selectors of positive or negative regulation from a single DNA element. Science 1990, 249, 1266-1272. [CrossRef]

34. Subramaniam, N.; Cairns, W.; Okret, S. Glucocorticoids repress transcription from a negative glucocorticoid response element recognized by two homeodomain-containing proteins, Pbx and Oct-1. J. Biol. Chem. 1998, 273, 23567-23574. [CrossRef]

35. Villa, A.; Santiago, J.; Belandia, B.; Pascual, A. A response unit in the first exon of the $\beta$-amyloid precursor protein gene containing thyroid hormone receptor and Sp1 binding sites mediates negative regulation by 3, 5, 3'-triiodothyronine. Mol. Endocrinol. 2004, 18, 863-873. [CrossRef]

36. Surjit, M.; Ganti, K.P.; Mukherji, A.; Ye, T.; Hua, G.; Metzger, D.; Li, M.; Chambon, P. Widespread negative response elements mediate direct repression by agonist-liganded glucocorticoid receptor. Cell 2011, 145, 224-241. [CrossRef]

37. Berghagen, H.; Ragnhildstveit, E.; Krogsrud, K.; Thuestad, G.; Apriletti, J.; Saatcioglu, F. Corepressor SMRT functions as a coactivator for thyroid hormone receptor T3R $\alpha$ from a negative hormone response element. J. Biol. Chem. 2002, 277, 49517-49522. [CrossRef]

38. Takeuchi, Y.; Murata, Y.; Sadow, P.; Hayashi, Y.; Seo, H.; Xu, J.; O’Malley, B.W.; Weiss, R.E.; Refetoff, S. Steroid receptor coactivator1 deficiency causes variable alterations in the modulation of T3-regulated transcription of genes in vivo. Endocrinology 2002, 143, 1346-1352. [CrossRef]

39. Weiss, R.E.; Xu, J.; Ning, G.; Pohlenz, J.; O'Malley, B.W.; Refetoff, S. Mice deficient in the steroid receptor co-activator 1 (SRC-1) are resistant to thyroid hormone. EMBO J. 1999, 18, 1900-1904. [CrossRef]

40. Wang, D.; Xia, X.; Weiss, R.E.; Refetoff, S.; Yen, P.M. Distinct and histone-specific modifications mediate positive versus negative transcriptional regulation of TSH $\alpha$ promoter. PLoS ONE 2010, 5, e9853. [CrossRef]

41. Auphan, N.; DiDonato, J.A.; Rosette, C.; Helmberg, A.; Karin, M. Immunosuppression by glucocorticoids: Inhibition of NF- $\kappa$ B activity through induction of IKB synthesis. Science 1995, 270, 286-290. [CrossRef] [PubMed]

42. Saijo, K.; Collier, J.G.; Li, A.C.; Katzenellenbogen, J.A.; Glass, C.K. An ADIOL-ER $\beta$-CtBP transrepression pathway negatively regulates microglia-mediated inflammation. Cell 2011, 145, 584-595. [CrossRef] [PubMed]

43. Evans, M.J.; Eckert, A.; Lai, K.; Adelman, S.J.; Harnish, D.C. Reciprocal antagonism between estrogen receptor and NF- $\kappa B$ activity in vivo. Circ. Res. 2001, 89, 823-830. [CrossRef] [PubMed]

44. Beck, I.M.; Vanden Berghe, W.; Vermeulen, L.; Yamamoto, K.R.; Haegeman, G.; De Bosscher, K. Crosstalk in inflammation: The interplay of glucocorticoid receptor-based mechanisms and kinases and phosphatases. Endocr. Rev. 2009, 30, 830-882. [CrossRef]

45. Ogawa, S.; Lozach, J.; Benner, C.; Pascual, G.; Tangirala, R.K.; Westin, S.; Hoffmann, A.; Subramaniam, S.; David, M.; Rosenfeld, M.G. Molecular determinants of crosstalk between nuclear receptors and toll-like receptors. Cell 2005, 122, 707-721. [CrossRef]

46. Sanchez-Pacheco, A.; Martínez-Iglesias, O.; Mendez-Pertuz, M.; Aranda, A. Residues K128, 132, and 134 in the thyroid hormone receptor- $\alpha$ are essential for receptor acetylation and activity. Endocrinology 2009, 150, 5143-5152. [CrossRef]

47. Benkoussa, M.; Brand, C.; Delmotte, M.-H.; Formstecher, P.; Lefebvre, P. Retinoic acid receptors inhibit AP1 activation by regulating extracellular signal-regulated kinase and CBP recruitment to an AP1-responsive promoter. Mol. Cell. Biol. 2002, 22, 4522-4534. [CrossRef]

48. Rauch, A.; Seitz, S.; Baschant, U.; Schilling, A.F.; Illing, A.; Stride, B.; Kirilov, M.; Takacz, A.; Schmidt-Ullrich, R.; Ostermay, S. Glucocorticoids suppress bone formation by attenuating osteoblast differentiation via the monomeric glucocorticoid receptor. Cell Metab. 2010, 11, 517-531. [CrossRef]

49. Fan, W.; Evans, R. PPARs and ERRs: Molecular mediators of mitochondrial metabolism. Curr. Opin. Cell Biol. 2015, 33, 49-54. [CrossRef]

50. Kota, B.P.; Huang, T.H.-W.; Roufogalis, B.D. An overview on biological mechanisms of PPARs. Pharm. Res. 2005, 51, 85-94. [CrossRef] 
51. Ahmed, W.; Ziouzenkova, O.; Brown, J.; Devchand, P.; Francis, S.; Kadakia, M.; Kanda, T.; Orasanu, G.; Sharlach, M.; Zandbergen, F. PPARs and their metabolic modulation: New mechanisms for transcriptional regulation? J. Intern. Med. 2007, 262, 184-198. [CrossRef]

52. Wu, J.; Chen, L.; Zhang, D.; Huo, M.; Zhang, X.; Pu, D.; Guan, Y. Peroxisome proliferator-activated receptors and renal diseases. Front. Biosci. 2009, 14, 995-1009. [CrossRef]

53. Dubois, V.; Eeckhoute, J.; Lefebvre, P.; Staels, B. Distinct but complementary contributions of PPAR isotypes to energy homeostasis. J. Clin. Investig. 2017, 127, 1202-1214. [CrossRef]

54. Kersten, S.; Desvergne, B.; Wahli, W. Roles of PPARs in health and disease. Nature 2000, 405, 421-424. [CrossRef]

55. Ahmed, I.; Rehman, S.U.; Shahmohamadnejad, S.; Zia, M.A.; Ahmad, M.; Saeed, M.M.; Akram, Z.; Iqbal, H.; Liu, Q. Therapeutic Attributes of Endocannabinoid System against Neuro-Inflammatory Autoimmune Disorders. Molecules 2021, 26, 3389. [CrossRef]

56. York, B.; O'Malley, B.W. Steroid receptor coactivator (SRC) family: Masters of systems biology. J. Biol. Chem. 2010, 285, 38743-38750. [CrossRef]

57. Liu, N.; Hayes, J.J. When push comes to shove: SWI/SNF uses a nucleosome to get rid of a nucleosome. Mol. Cell 2010, 38 , 484-486. [CrossRef]

58. Chiba, H.; Muramatsu, M.; Nomoto, A.; Kato, H. Two human homologues of Saccharomyces cerevisiae SWI2/SNF2 and Drosophila brahma are transcriptional coactivators cooperating with the estrogen receptor and the retinoic acid receptor. Nucleic Acids Res. 1994, 22, 1815-1820. [CrossRef]

59. Link, K.A.; Burd, C.J.; Williams, E.; Marshall, T.; Rosson, G.; Henry, E.; Weissman, B.; Knudsen, K.E. BAF57 governs androgen receptor action and androgen-dependent proliferation through SWI/SNF. Mol. Cell. Biol. 2005, 25, 2200-2215. [CrossRef]

60. Miao, J.; Fang, S.; Lee, J.; Comstock, C.; Knudsen, K.E.; Kemper, J.K. Functional specificities of Brm and Brg-1 Swi/Snf ATPases in the feedback regulation of hepatic bile acid biosynthesis. Mol. Cell. Biol. 2009, 29, 6170-6181. [CrossRef]

61. Hsiao, P.-W.; Fryer, C.J.; Trotter, K.W.; Wang, W.; Archer, T.K. BAF60a mediates critical interactions between nuclear receptors and the BRG1 chromatin-remodeling complex for transactivation. Mol. Cell. Biol. 2003, 23, 6210-6220. [CrossRef]

62. Kemper, J.K.; Kim, H.; Miao, J.; Bhalla, S.; Bae, Y. Role of an mSin3A-Swi/Snf chromatin remodeling complex in the feedback repression of bile acid biosynthesis by SHP. Mol. Cell. Biol. 2004, 24, 7707-7719. [CrossRef]

63. Underhill, C.; Qutob, M.S.; Yee, S.-P.; Torchia, J. A novel nuclear receptor corepressor complex, N-CoR, contains components of the mammalian SWI/SNF complex and the corepressor KAP-1. J. Biol. Chem. 2000, 275, 40463-40470. [CrossRef]

64. Tao, W.; Chen, S.; Shi, G.; Guo, J.; Xu, Y.; Liu, C. SWItch/sucrose nonfermentable (SWI/SNF) complex subunit BAF60a integrates hepatic circadian clock and energy metabolism. Hepatology 2011, 54, 1410-1420. [CrossRef]

65. Conaway, R.C.; Conaway, J.W. Origins and activity of the Mediator complex. Semin. Cell Dev. Biol. 2011, 22, 729-734. [CrossRef]

66. Taatjes, D.J. The human Mediator complex: A versatile, genome-wide regulator of transcription. Trends Biochem. Sci. 2010, 35, 315-322. [CrossRef]

67. Bai, L.; Jia, Y.; Viswakarma, N.; Huang, J.; Vluggens, A.; Wolins, N.E.; Jafari, N.; Rao, M.S.; Borensztajn, J.; Yang, G. Transcription coactivator mediator subunit MED1 is required for the development of fatty liver in the mouse. Hepatology 2011, 53, 1164-1174. [CrossRef]

68. Ge, K.; Cho, Y.-W.; Guo, H.; Hong, T.B.; Guermah, M.; Ito, M.; Yu, H.; Kalkum, M.; Roeder, R.G. Alternative mechanisms by which mediator subunit MED1/TRAP220 regulates peroxisome proliferator-activated receptor $\gamma$-stimulated adipogenesis and target gene expression. Mol. Cell. Biol. 2008, 28, 1081-1091. [CrossRef]

69. Ge, K.; Guermah, M.; Yuan, C.-X.; Ito, M.; Wallberg, A.E.; Spiegelman, B.M.; Roeder, R.G. Transcription coactivator TRAP220 is required for PPAR $\gamma 2$-stimulated adipogenesis. Nature 2002, 417, 563-567. [CrossRef]

70. Pyper, S.R.; Viswakarma, N.; Yu, S.; Reddy, J.K. PPAR $\alpha$ : Energy combustion, hypolipidemia, inflammation and cancer. Nucl. Recept. Signal. 2010, 8, nrs.08002. [CrossRef]

71. Dressel, U.; Allen, T.L.; Pippal, J.B.; Rohde, P.R.; Lau, P.; Muscat, G.E. The peroxisome proliferator-activated receptor $\beta / \delta$ agonist, GW501516, regulates the expression of genes involved in lipid catabolism and energy uncoupling in skeletal muscle cells. Mol. Endocrinol. 2003, 17, 2477-2493. [CrossRef] [PubMed]

72. Lefebvre, P.; Chinetti, G.; Fruchart, J.-C.; Staels, B. Sorting out the roles of PPAR $\alpha$ in energy metabolism and vascular homeostasis. J. Clin. Investig. 2006, 116, 571-580. [CrossRef] [PubMed]

73. Feingold, K.R.; Wang, Y.; Moser, A.; Shigenaga, J.K.; Grunfeld, C. LPS decreases fatty acid oxidation and nuclear hormone receptors in the kidney. J. Lipid Res. 2008, 49, 2179-2187. [CrossRef] [PubMed]

74. Choe, S.S.; Huh, J.Y.; Hwang, I.J.; Kim, J.I.; Kim, J.B. Adipose tissue remodeling: Its role in energy metabolism and metabolic disorders. Front. Endocrinol. 2016, 7, 30. [CrossRef]

75. Birsoy, K.; Festuccia, W.T.; Laplante, M. A comparative perspective on lipid storage in animals. J. Cell Sci. 2013, 126, 1541-1552. [CrossRef] [PubMed]

76. Rosen, E.D.; Spiegelman, B.M. Adipocytes as regulators of energy balance and glucose homeostasis. Nature 2006, 444, 847-853. [CrossRef] [PubMed]

77. Tontonoz, P.; Hu, E.; Graves, R.A.; Budavari, A.I.; Spiegelman, B.M. mPPAR gamma 2: Tissue-specific regulator of an adipocyte enhancer. Genes Dev. 1994, 8, 1224-1234. [CrossRef] [PubMed]

78. Tontonoz, P.; Hu, E.; Spiegelman, B.M. Stimulation of adipogenesis in fibroblasts by PPAR $\gamma 2$, a lipid-activated transcription factor. Cell 1994, 79, 1147-1156. [CrossRef] 
79. Rosen, E.D.; Hsu, C.-H.; Wang, X.; Sakai, S.; Freeman, M.W.; Gonzalez, F.J.; Spiegelman, B.M. C/EBP $\alpha$ induces adipogenesis through PPAR $\gamma$ : A unified pathway. Genes Dev. 2002, 16, 22-26. [CrossRef]

80. Mullican, S.E.; DiSpirito, J.R.; Lazar, M.A. The orphan nuclear receptors at their 25-year reunion. J. Mol. Endocrinol. 2013, 51, T115-T140. [CrossRef]

81. Liu, Y.; Huang, J.; Hou, Y.; Zhu, H.; Zhao, S.; Ding, B.; Yin, Y.; Yi, G.; Shi, J.; Fan, W. Dietary arginine supplementation alleviates intestinal mucosal disruption induced by Escherichia coli lipopolysaccharide in weaned pigs. Br. J. Nutr. 2008, 100, 552-560. [CrossRef]

82. Shi, H.; Luo, J.; Zhu, J.; Li, J.; Sun, Y.; Lin, X.; Zhang, L.; Yao, D.; Shi, H. PPAR $\gamma$ regulates genes involved in triacylglycerol synthesis and secretion in mammary gland epithelial cells of dairy goats. PPAR Res. 2013, 2013, 310948. [CrossRef]

83. Shi, H.; Zhang, C.; Zhao, W.; Luo, J.; Loor, J. Peroxisome proliferator-activated receptor delta facilitates lipid secretion and catabolism of fatty acids in dairy goat mammary epithelial cells. J. Dairy Sci. 2017, 100, 797-806. [CrossRef]

84. Manickam, R.; Wahli, W. Roles of Peroxisome Proliferator-Activated Receptor $\beta / \delta$ in skeletal muscle physiology. Biochimie 2017, 136, 42-48. [CrossRef]

85. Cho, S.Y.; Jeong, H.W.; Sohn, J.H.; Seo, D.-B.; Kim, W.G.; Lee, S.-J. An ethanol extract of Artemisia iwayomogi activates PPAR $\delta$ leading to activation of fatty acid oxidation in skeletal muscle. PLOS ONE 2012, 7, e33815. [CrossRef]

86. Periasamy, M.; Herrera, J.L.; Reis, F.C. Skeletal muscle thermogenesis and its role in whole body energy metabolism. Diabetes Metab. J. 2017, 41, 327-336. [CrossRef]

87. Gan, Z.; Burkart-Hartman, E.M.; Han, D.-H.; Finck, B.; Leone, T.C.; Smith, E.Y.; Ayala, J.E.; Holloszy, J.; Kelly, D.P. The nuclear receptor PPAR $\beta / \delta$ programs muscle glucose metabolism in cooperation with AMPK and MEF2. Genes Dev. 2011, 25, 2619-2630. [CrossRef]

88. Lamichane, S.; Lamichane, B.D.; Kwon, S.-M. Pivotal Roles of Peroxisome Proliferator-Activated. PPARs Cell. Whole Body Energy Metab. 2019, 19, 382.

89. Pérez-Schindler, J.; Svensson, K.; Vargas-Fernández, E.; Santos, G.; Wahli, W.; Handschin, C. The coactivator PGC-1 $\alpha$ regulates skeletal muscle oxidative metabolism independently of the nuclear receptor PPAR $\beta / \delta$ in sedentary mice fed a regular chow diet. Diabetologia 2014, 57, 2405-2412. [CrossRef]

90. Thach, T.T.; Lee, C.-K.; woo Park, H.; Lee, S.-J.; Lee, S.-J. Syringaresinol induces mitochondrial biogenesis through activation of PPAR $\beta$ pathway in skeletal muscle cells. Bioorgan. Med. Chem. Lett. 2016, 26, 3978-3983. [CrossRef]

91. Vrins, C.L.; van der Velde, A.E.; van den Oever, K.; Levels, J.H.; Huet, S.; Elferink, R.P.O.; Kuipers, F.; Groen, A.K. Peroxisome proliferator-activated receptor delta activation leads to increased transintestinal cholesterol efflux. J. Lipid Res. 2009, 50, $2046-2054$. [CrossRef]

92. Higashimura, Y.; Naito, Y.; TAkAGI, T.; Uchiyama, K.; Mizushima, K.; YOSHIkAWA, T. Propionate promotes fatty acid oxidation through the up-regulation of peroxisome proliferator-activated receptor $\alpha$ in intestinal epithelial cells. J. Nutri. Sci. Vitaminol. 2015, 61, 511-515. [CrossRef]

93. Korecka, A.; de Wouters, T.; Cultrone, A.; Lapaque, N.; Pettersson, S.; Doré, J.; Blottière, H.M.; Arulampalam, V. ANGPTL4 expression induced by butyrate and rosiglitazone in human intestinal epithelial cells utilizes independent pathways. Am. J. Physiol.-Gastrointest. Liver Physiol. 2013, 304, G1025-G1037. [CrossRef]

94. Azari, E.K.; Leitner, C.; Jaggi, T.; Langhans, W.; Mansouri, A. Possible role of intestinal fatty acid oxidation in the eating-inhibitory effect of the PPAR- $\alpha$ agonist Wy-14643 in high-fat diet fed rats. PLoS ONE 2013, 8, e74869.

95. Bünger, M.; de Groot, P.J.; Bosch-Vermeulen, H.; Hooiveld, G.J.; Müller, M. PPARalpha-mediated effects of dietary lipids on intestinal barrier gene expression. BMC Genom. 2008, 9, 231.

96. Van den Bosch, H.M.; Bünger, M.; de Groot, P.J.; van der Meijde, J.; Hooiveld, G.J.; Müller, M. Gene expression of transporters and phase I/II metabolic enzymes in murine small intestine during fasting. BMC Genom. 2007, 8, 267. [CrossRef]

97. Takei, K.; Nakagawa, Y.; Wang, Y.; Han, S.-i.; Satoh, A.; Sekiya, M.; Matsuzaka, T.; Shimano, H. Effects of K-877, a novel selective PPAR $\alpha$ modulator, on small intestine contribute to the amelioration of hyperlipidemia in low-density lipoprotein receptor knockout mice. J. Pharmacol. Sci. 2017, 133, 214-222. [CrossRef]

98. Lempradl, A.; Pospisilik, J.A.; Penninger, J.M. Exploring the emerging complexity in transcriptional regulation of energy homeostasis. Nat. Rev. Genet. 2015, 16, 665-681. [CrossRef]

99. Yamamoto, H.; Williams, E.G.; Mouchiroud, L.; Canto, C.; Fan, W.; Downes, M.; Héligon, C.; Barish, G.D.; Desvergne, B.; Evans, R.M. NCoR1 is a conserved physiological modulator of muscle mass and oxidative function. Cell 2011, 147, 827-839. [CrossRef]

100. Martinez-Jimenez, C.P.; Kyrmizi, I.; Cardot, P.; Gonzalez, F.J.; Talianidis, I. Hepatocyte nuclear factor $4 \alpha$ coordinates a transcription factor network regulating hepatic fatty acid metabolism. Mol. Cell. Biol. 2010, 30, 565-577. [CrossRef]

101. Tyagi, S.; Gupta, P.; Saini, A.S.; Kaushal, C.; Sharma, S. The peroxisome proliferator-activated receptor: A family of nuclear receptors role in various diseases. J. Adv. Pharm. Technol. Res. 2011, 2, 236. [CrossRef] [PubMed]

102. Krey, G.; Braissant, O.; L’Horset, F.; Kalkhoven, E.; Perroud, M.; Parker, M.G.; Wahli, W. Fatty acids, eicosanoids, and hypolipidemic agents identified as ligands of peroxisome proliferator-activated receptors by coactivator-dependent receptor ligand assay. Mol. Endocrinol. 1997, 11, 779-791. [CrossRef] [PubMed]

103. Itoh, T.; Fairall, L.; Amin, K.; Inaba, Y.; Szanto, A.; Balint, B.L.; Nagy, L.; Yamamoto, K.; Schwabe, J.W. Structural basis for the activation of PPAR $\gamma$ by oxidized fatty acids. Nat. Struct. Mol. Biol. 2008, 15, 924-931. [CrossRef] [PubMed] 
104. Xu, H.E.; Lambert, M.H.; Montana, V.G.; Parks, D.J.; Blanchard, S.G.; Brown, P.J.; Sternbach, D.D.; Lehmann, J.M.; Wisely, G.B.; Willson, T.M. Molecular recognition of fatty acids by peroxisome proliferator-activated receptors. Mol. Cell 1999, 3, $397-403$. [CrossRef]

105. Cavalieri, D.; Calura, E.; Romualdi, C.; Marchi, E.; Radonjic, M.; Van Ommen, B.; Müller, M. Filling gaps in PPAR-alpha signaling through comparative nutrigenomics analysis. BMC Genom. 2009, 10, 596. [CrossRef]

106. Sanderson, L.M.; de Groot, P.J.; Hooiveld, G.J.; Koppen, A.; Kalkhoven, E.; Müller, M.; Kersten, S. Effect of synthetic dietary triglycerides: A novel research paradigm for nutrigenomics. PLoS ONE 2008, 3, e1681. [CrossRef]

107. Yoon, J.C.; Puigserver, P.; Chen, G.; Donovan, J.; Wu, Z.; Rhee, J.; Adelmant, G.; Stafford, J.; Kahn, C.R.; Granner, D.K. Control of hepatic gluconeogenesis through the transcriptional coactivator PGC-1. Nature 2001, 413, 131-138. [CrossRef]

108. Rakhshandehroo, M.; Knoch, B.; Müller, M.; Kersten, S. Peroxisome proliferator-activated receptor alpha target genes. PPAR Res. 2010, 2010, 612089. [CrossRef]

109. Schmitz, G.; Ecker, J. The opposing effects of $\mathrm{n}-3$ and $\mathrm{n}-6$ fatty acids. Prog. Lipid Res. 2008, 47, 147-155. [CrossRef]

110. Khan, S.A.; Heuvel, J.P.V. Reviews: Current topicsrole of nuclear receptors in the regulation of gene expression by dietary fatty acids. J. Nutr. Biochem. 2003, 14, 554-567. [CrossRef]

111. Power, G.W.; Newsholme, E.A. Dietary fatty acids influence the activity and metabolic control of mitochondrial carnitine palmitoyltransferase I in rat heart and skeletal muscle. J. Nutr. 1997, 127, 2142-2150. [CrossRef]

112. Yu, K.; Bayona, W.; Kallen, C.B.; Harding, H.P.; Ravera, C.P.; McMahon, G.; Brown, M.; Lazar, M.A. Differential activation of peroxisome proliferator-activated receptors by eicosanoids. J. Biol. Chem. 1995, 270, 23975-23983. [CrossRef]

113. Borrelli, F.; Izzo, A.A. Role of acylethanolamides in the gastrointestinal tract with special reference to food intake and energy balance. Best Pract. Res. Clin. Endocrinol. Metab. 2009, 23, 33-49. [CrossRef]

114. O'Sullivan, S. Cannabinoids go nuclear: Evidence for activation of peroxisome proliferator-activated receptors. Br. J. Pharmacol. 2007, 152, 576-582. [CrossRef]

115. Huber, J.; Löffler, M.; Bilban, M.; Reimers, M.; Kadl, A.; Todoric, J.; Zeyda, M.; Geyeregger, R.; Schreiner, M.; Weichhart, T. Prevention of high-fat diet-induced adipose tissue remodeling in obese diabetic mice by n-3 polyunsaturated fatty acids. Int. J. Obesity 2007, 31, 1004-1013. [CrossRef]

116. Kim, S.; Shin, H.-J.; Kim, S.Y.; Kim, J.H.; Lee, Y.S.; Kim, D.-H.; Lee, M.-O. Genistein enhances expression of genes involved in fatty acid catabolism through activation of PPAR $\alpha$. Mol. Cell. Endocrinol. 2004, 220, 51-58. [CrossRef]

117. Ricketts, M.-L.; Moore, D.D.; Banz, W.J.; Mezei, O.; Shay, N.F. Molecular mechanisms of action of the soy isoflavones includes activation of promiscuous nuclear receptors. A review. J. Nutr. Biochem. 2005, 16, 321-330. [CrossRef]

118. Mezei, O.; Li, Y.; Mullen, E.; Ross-Viola, J.S.; Shay, N.F. Dietary isoflavone supplementation modulates lipid metabolism via PPAR $\alpha$-dependent and-independent mechanisms. Physiol. Genom. 2006, 26, 8-14. [CrossRef]

119. Yeh, S.-L.; Yeh, C.-L.; Chan, S.-T.; Chuang, C.-H. Plasma rich in quercetin metabolites induces G2/M arrest by upregulating PPAR- $\gamma$ expression in human A549 lung cancer cells. Planta Med. 2011, 77, 992-998. [CrossRef]

120. Kobori, M.; Masumoto, S.; Akimoto, Y.; Oike, H. Chronic dietary intake of quercetin alleviates hepatic fat accumulation associated with consumption of a Western-style diet in C57/BL6J mice. Mol. Nutr. Food Res. 2011, 55, 530-540. [CrossRef]

121. McMichael-Phillips, D.F.; Harding, C.; Morton, M.; Roberts, S.A.; Howell, A.; Potten, C.S.; Bundred, N.J. Effects of soy-protein supplementation on epithelial proliferation in the histologically normal human breast. Am. J. Clin. Nutr. 1998, 68, 1431S-1435S [CrossRef] [PubMed]

122. Alibin, C.P.; Kopilas, M.A.; Anderson, H.D. Suppression of Cardiac Myocyte Hypertrophy by Conjugated Linoleic Acid Role of Peroxisome Proliferator-Activated Receptors $\alpha$ and $\gamma$. J. Biol. Chem. 2008, 283, 10707-10715. [CrossRef] [PubMed]

123. Hodge, G.; Hodge, S.; Han, P. Allium sativum (garlic) suppresses leukocyte inflammatory cytokine production in vitro: Potential therapeutic use in the treatment of inflammatory bowel disease. Cytom. J. Int. Soc. Anal. Cytol. 2002, 48, 209-215. [CrossRef] [PubMed]

124. Iciek, M.; Kwiecień, I.; Włodek, L. Biological properties of garlic and garlic-derived organosulfur compounds. Environ. Mol. Mutagenes. 2009, 50, 247-265. [CrossRef]

125. Sato, N.; Moore, F.; Kone, B.; Zou, L.; Smith, M.; Childs, M.; Moore-Olufemi, S.; Schultz, S.; Kozar, R. Differential induction of PPAR- $\gamma$ by luminal glutamine and iNOS by luminal arginine in the rodent postischemic small bowel. Am. J. Physiol.-Gastrointest. Liver Physiol. 2006, 290, G616-G623. [CrossRef]

126. Von Lintig, J. Colors with functions: Elucidating the biochemical and molecular basis of carotenoid metabolism. Annu. Rev. Nutr. 2010, 30, 35-56. [CrossRef]

127. Ortuño Sahagún, D.; Márquez-Aguirre, A.; Quintero-Fabián, S.; López-Roa, R.; Rojas-Mayorquín, A. Modulation of PPAR- $\gamma$ by nutraceutics as complementary treatment for obesity-related disorders and inflammatory diseases. PPAR Res. 2012, $2012,318613$. [CrossRef]

128. Ford, E.S.; Will, J.C.; Bowman, B.A.; Narayan, K.V. Diabetes mellitus and serum carotenoids: Findings from the Third National Health and Nutrition Examination Survey. Am. J. Epidemiol. 1999, 149, 168-176. [CrossRef]

129. Ylönen, K.; Alfthan, G.; Groop, L.; Saloranta, C.; Aro, A.; Virtanen, S.M.; Group, B.R. Dietary intakes and plasma concentrations of carotenoids and tocopherols in relation to glucose metabolism in subjects at high risk of type 2 diabetes: The Botnia Dietary Study. Am. J. Clin. Nutr. 2003, 77, 1434-1441. [CrossRef] 
130. Coyne, T.; Ibiebele, T.I.; Baade, P.D.; Dobson, A.; McClintock, C.; Dunn, S.; Leonard, D.; Shaw, J. Diabetes mellitus and serum carotenoids: Findings of a population-based study in Queensland, Australia. Am. J. Clin. Nutr. 2005, 82, 685-693. [CrossRef]

131. Burrows, T.L.; Warren, J.M.; Colyvas, K.; Garg, M.L.; Collins, C.E. Validation of overweight children's fruit and vegetable intake using plasma carotenoids. Obesity 2009, 17, 162-168. [CrossRef]

132. Hessel, S.; Eichinger, A.; Isken, A.; Amengual, J.; Hunzelmann, S.; Hoeller, U.; Elste, V.; Hunziker, W.; Goralczyk, R.; Oberhauser, V. CMO1 deficiency abolishes vitamin A production from $\beta$-carotene and alters lipid metabolism in mice. J. Biol. Chem. 2007, 282, 33553-33561. [CrossRef]

133. Boulanger, A.; McLemore, P.; Copeland, N.G.; Gilbert, D.J.; Jenkins, N.A.; Yu, S.S.; Gentleman, S.; Redmond, T.M. Identification of beta-carotene 15, 15'-monooxygenase as a peroxisome proliferator-activated receptor target gene. FASEB J. 2003, 17, 1304-1306. [CrossRef]

134. Gong, X.; Tsai, S.-W.; Yan, B.; Rubin, L.P. Cooperation between MEF2 and PPAR $\gamma$ in human intestinal $\beta, \beta$-carotene 15, 15'monooxygenase gene expression. BMC Mol. Biol. 2006, 7, 7. [CrossRef]

135. Lobo, G.P.; Amengual, J.; Li, H.N.M.; Golczak, M.; Bonet, M.L.; Palczewski, K.; Von Lintig, J. $\beta$, $\beta$-carotene decreases peroxisome proliferator receptor $\gamma$ activity and reduces lipid storage capacity of adipocytes in a $\beta, \beta$-carotene oxygenase 1-dependent manner. J. Biol. Chem. 2010, 285, 27891-27899. [CrossRef]

136. Ziouzenkova, O.; Orasanu, G.; Sharlach, M.; Akiyama, T.E.; Berger, J.P.; Viereck, J.; Hamilton, J.A.; Tang, G.; Dolnikowski, G.G.; Vogel, S. Retinaldehyde represses adipogenesis and diet-induced obesity. Nat. Med. 2007, 13, 695-702. [CrossRef]

137. Eroglu, A.; Hruszkewycz, D.P.; Curley, R.W., Jr;; Harrison, E.H. The eccentric cleavage product of $\beta$-carotene, $\beta$-apo-13-carotenone, functions as an antagonist of RXR $\alpha$. Arch. Biochem. Biophys. 2010, 504, 11-16. [CrossRef]

138. Amengual, J.; Gouranton, E.; van Helden, Y.G.; Hessel, S.; Ribot, J.; Kramer, E.; Kiec-Wilk, B.; Razny, U.; Lietz, G.; Wyss, A. Beta-carotene reduces body adiposity of mice via BCMO1. PLoS ONE 2011, 6, e20644. [CrossRef]

139. Wang, X.; Quinn, P.J. Vitamin E and its function in membranes. Prog. Lipid Res. 1999, 38, 309-336. [CrossRef]

140. Constantinou, C.; Papas, A.; Constantinou, A.I. Vitamin E and cancer: An insight into the anticancer activities of vitamin E isomers and analogs. Int. J. Cancer 2008, 123, 739-752. [CrossRef]

141. Traber, M.G. Vitamin E regulatory mechanisms. Annu. Rev. Nutr. 2007, 27, 347-362. [CrossRef]

142. Ross, A.C.; Caballero, B.; Cousins, R.J.; Tucker, K.L.; Ziegler, T.R. Modern Nutrition in Health and Disease, 11th ed.; Williams \& Wilkins: Philadelphia, PA, USA, 2006.

143. Stone, W.L.; Krishnan, K.; Campbell, S.E.; Qui, M.; Whaley, S.G.; Yang, H. Tocopherols and the treatment of colon cancer. Ann. N. Y. Acad. Sci. 2004, 1031, 223-233. [CrossRef]

144. Campbell, S.E.; Stone, W.L.; Whaley, S.G.; Qui, M.; Krishnan, K. Gamma $(\gamma)$ tocopherol upregulates peroxisome proliferator activated receptor (PPAR) gamma $(\gamma)$ expression in SW 480 human colon cancer cell lines. BMC Cancer 2003, 3, 25. [CrossRef]

145. Qureshi, A.A.; Tan, X.; Reis, J.C.; Badr, M.Z.; Papasian, C.J.; Morrison, D.C.; Qureshi, N. Inhibition of nitric oxide in LPS-stimulated macrophages of young and senescent mice by $\delta$-tocotrienol and quercetin. Lipids Health Dis. 2011, 10, 239. [CrossRef]

146. Qureshi, A.A.; Reis, J.C.; Qureshi, N.; Papasian, C.J.; Morrison, D.C.; Schaefer, D.M. $\delta$-Tocotrienol and quercetin reduce serum levels of nitric oxide and lipid parameters in female chickens. Lipids Health Dis. 2011, 10, 39. [CrossRef]

147. Mosca, A.; Paleari, R.; Ivaldi, G.; Galanello, R.; Giordano, P. The role of haemoglobin A2 testing in the diagnosis of thalassaemias and related haemoglobinopathies. J. Clin. Pathol. 2009, 62, 13-17. [CrossRef]

148. Uto-Kondo, H.; Ohmori, R.; Kiyose, C.; Kishimoto, Y.; Saito, H.; Igarashi, O.; Kondo, K. Tocotrienol suppresses adipocyte differentiation and Akt phosphorylation in 3T3-L1 preadipocytes. J. Nutr. 2009, 139, 51-57. [CrossRef]

149. Ribot, J.; Felipe, F.; Bonet, M.L.; Palou, A. Changes of adiposity in response to vitamin A status correlate with changes of PPAR 2 expression. Obesity Res. 2001, 9, 500-509. [CrossRef]

150. Kuri-Harcuch, W. Differentiation of 3T3-F442A cells into adipocytes is inhibited by retinoic acid. Differentiation 1982, 23, 164-169. [CrossRef] [PubMed]

151. Schwarz, E.J.; Reginato, M.J.; Shao, D.; Krakow, S.L.; Lazar, M.A. Retinoic acid blocks adipogenesis by inhibiting C/EBPbetamediated transcription. Mol. Cell. Biol. 1997, 17, 1552-1561. [CrossRef] [PubMed]

152. Duque, G.; Macoritto, M.; Kremer, R. 1,25(OH) $)_{2} \mathrm{D}_{3}$ inhibits bone marrow adipogenesis in senescence accelerated mice (SAM-P/6) by decreasing the expression of peroxisome proliferator-activated receptor gamma 2 (PPAR 2 ). Exp. Gerontol. 2004, 39, 333-338. [CrossRef] [PubMed]

153. Hida, Y.; Kawada, T.; Kayahashi, S.; Ishihara, T.; Fushiki, T. Counteraction of retinoic acid and 1, 25-dihydroxyvitamin D3 on up-regulation of adipocyte differentiation with PPAR $\gamma$ ligand, an antidiabetic thiazolidinedione, in 3T3-L1 cells. Life Sci. 1998, 62, PL205-PL211. [CrossRef]

154. Sirtori, C.R.; Arnoldi, A.; Johnson, S.K. Phytoestrogens: End of a tale? Ann. Med. 2005, 37, 423-438. [CrossRef] [PubMed]

155. Bajaj, M.; Hinge, A.; Limaye, L.S.; Gupta, R.K.; Surolia, A.; Kale, V.P. Mannose-binding dietary lectins induce adipogenic differentiation of the marrow-derived mesenchymal cells via an active insulin-like signaling mechanism. Glycobiology 2011, 21, 521-529. [CrossRef]

156. Dang, Z.-C.; Audinot, V.; Papapoulos, S.E.; Boutin, J.A.; Löwik, C.W. Peroxisome proliferator-activated receptor $\gamma($ PPAR $\gamma)$ as a molecular target for the soy phytoestrogen genistein. J. Biol. Chem. 2003, 278, 962-967. [CrossRef]

157. Sangeetha, T.; Quine, S.D. Protective effect of S-allyl cysteine sulphoxide (alliin) on glycoproteins and hematology in isoproterenol induced myocardial infarction in male Wistar rats. J. Appl. Toxicol. 2008, 28, 710-716. [CrossRef] 
158. Keophiphath, M.; Priem, F.; Jacquemond-Collet, I.; Clément, K.; Lacasa, D. 1,2-vinyldithiin from garlic inhibits differentiation and inflammation of human preadipocytes. J. Nutr. 2009, 139, 2055-2060. [CrossRef]

159. Adapala, N.; Chan, M.M. Long-term use of an antiinflammatory, curcumin, suppressed type 1 immunity and exacerbated visceral leishmaniasis in a chronic experimental model. Lab. Investig. 2008, 88, 1329-1339. [CrossRef]

160. Dos Santos Costa, C.; Rohden, F.; Hammes, T.O.; Margis, R.; Bortolotto, J.W.; Padoin, A.V.; Mottin, C.C.; Guaragna, R.M Resveratrol upregulated SIRT1, FOXO1, and adiponectin and downregulated PPAR $\gamma 1-3$ mRNA expression in human visceral adipocytes. Obesity Surg. 2011, 21, 356-361. [CrossRef]

161. Xu, Z.; Chen, X.; Zhong, Z.; Chen, L.; Wang, Y. Ganoderma lucidum polysaccharides: Immunomodulation and potential anti-tumor activities. Am. J. Chin. Med. 2011, 39, 15-27. [CrossRef]

162. Sawant, R.; Godghate, A. Qualitative phytochemical screening of rhizomes of Curcuma longa Linn. Int. J. Sci. Environ. 2013, 2, 634-641.

163. Hinge, A.; Bajaj, M.; Limaye, L.; Surolia, A.; Kale, V. Oral administration of insulin receptor-interacting lectins leads to an enhancement in the hematopoietic stem and progenitor cell pool of mice. Stem Cells Development 2010, 19, 163-174. [CrossRef]

164. Rayalam, S.; Della-Fera, M.A.; Yang, J.-Y.; Park, H.J.; Ambati, S.; Baile, C.A. Resveratrol potentiates genistein's antiadipogenic and proapoptotic effects in 3T3-L1 adipocytes. J. Nutr. 2007, 137, 2668-2673. [CrossRef]

165. Bionaz, M.; Hausman, G.J.; Loor, J.J.; Mandard, S. Physiological and nutritional roles of PPAR across species. PPAR Res. 2013, 2013, 807156. [CrossRef]

166. Oliveira, A.C.P.; Bertollo, C.M.; Rocha, L.T.S.; Nascimento, E.B., Jr.; Costa, K.A.; Coelho, M.M. Antinociceptive and antiedematogenic activities of fenofibrate, an agonist of PPAR alpha, and pioglitazone, an agonist of PPAR gamma. Eur. J. Pharmacol. 2007, 561, 194-201. [CrossRef]

167. Bionaz, M.; Loor, J.J. ACSL1, AGPAT6, FABP3, LPIN1, and SLC27A6 are the most abundant isoforms in bovine mammary tissue and their expression is affected by stage of lactation. J. Nutr. 2008, 138, 1019-1024. [CrossRef]

168. Varga, T.; Czimmerer, Z.; Nagy, L. PPARs are a unique set of fatty acid regulated transcription factors controlling both lipid metabolism and inflammation. Biochim. Biophys. Acta (BBA)—Mol. Basis Dis. 2011, 1812, 1007-1022. [CrossRef]

169. Kushibiki, S.; Hodate, K.; Shingu, H.; Ueda, Y.; Shinoda, M.; Mori, Y.; Itoh, T.; Yokomizo, Y. Insulin resistance induced in dairy steers by tumor necrosis factor alpha is partially reversed by 2, 4-thiazolidinedione. Domestic Anim. Endocrinol. 2001, 21, 25-37. [CrossRef]

170. Hauner, H. The mode of action of thiazolidinediones. Diabetes/Metabolism Res. Rev. 2002, 18, S10-S15. [CrossRef]

171. Perdomo, M.C.; Santos, J.E.; Badinga, L. Trans-10, cis-12 conjugated linoleic acid and the PPAR- $\gamma$ agonist rosiglitazone attenuate lipopolysaccharide-induced TNF- $\alpha$ production by bovine immune cells. Domest. Anim. Endocrinol. 2011, 41, 118-125. [CrossRef]

172. He, X.; Gao, J.; Hou, H.; Qi, Z.; Chen, H.; Zhang, X.-X. Inhibition of mitochondrial fatty acid oxidation contributes to development of nonalcoholic fatty liver disease induced by environmental cadmium exposure. Environ. Sci. Technol. 2019, 53, 13992-14000. [CrossRef]

173. Filip-Ciubotaru, F.; Foia, L.; Manciuc, C.; Grigore, C. PPARs: Structure, mechanisms of action and control. Note I. Revista Medico-Chirurgicala a Societatii de Medici si Naturalisti din Iasi 2011, 115, 477-484.

174. Hasan, A.U.; Rahman, A.; Kobori, H. Interactions between host PPARs and gut microbiota in health and disease. Int. J. Mol. Sci. 2019, 20, 387. [CrossRef]

175. Hasan, A.U.; Ohmori, K.; Hashimoto, T.; Kamitori, K.; Yamaguchi, F.; Rahman, A.; Tokuda, M.; Kobori, H. PPAR $\gamma$ activation mitigates glucocorticoid receptor-induced excessive lipolysis in adipocytes via homeostatic crosstalk. J. Cell. Biochem. 2018, 119, 4627-4635. [CrossRef]

176. Kersten, S. Regulation of lipid metabolism via angiopoietin-like proteins. Biochem. Soc. Trans. 2005, 33, 1059-1062. [CrossRef]

177. Kharitonenkov, A.; Shiyanova, T.L.; Koester, A.; Ford, A.M.; Micanovic, R.; Galbreath, E.J.; Sandusky, G.E.; Hammond, L.J.; Moyers, J.S.; Owens, R.A. FGF-21 as a novel metabolic regulator. J. Clin. Investig. 2005, 115, 1627-1635. [CrossRef]

178. Loor, J.J.; Everts, R.E.; Bionaz, M.; Dann, H.M.; Morin, D.E.; Oliveira, R.; Rodriguez-Zas, S.L.; Drackley, J.K.; Lewin, H.A. Nutrition-induced ketosis alters metabolic and signaling gene networks in liver of periparturient dairy cows. Physiol. Genom. 2007, 32, 105-116. [CrossRef]

179. Schoenberg, K.M.; Giesy, S.L.; Harvatine, K.J.; Waldron, M.R.; Cheng, C.; Kharitonenkov, A.; Boisclair, Y.R. Plasma FGF21 is elevated by the intense lipid mobilization of lactation. Endocrinology 2011, 152, 4652-4661. [CrossRef]

180. Riahi, Y.; Sin-Malia, Y.; Cohen, G.; Alpert, E.; Gruzman, A.; Eckel, J.; Staels, B.; Guichardant, M.; Sasson, S. The Natural Protective Mechanism Against Hyperglycemia in Vascular Endothelial Cells: Roles of the Lipid Peroxidation Product 4-Hydroxydodecadienal and Peroxisome Proliferator-Activated Receptor $\delta$. Diabetes 2010, 59, 808-818. [CrossRef]

181. Bionaz, M.; Trevisi, E.; Calamari, L.; Librandi, F.; Ferrari, A.; Bertoni, G. Plasma paraoxonase, health, inflammatory conditions, and liver function in transition dairy cows. J. Dairy Sci. 2007, 90, 1740-1750. [CrossRef]

182. Bionaz, M.; Loor, J.J. Gene networks driving bovine mammary protein synthesis during the lactation cycle. Bioinform. Biol. Insights 2011, 5, BBI.S7003. [CrossRef] [PubMed]

183. Bionaz, M.; Periasamy, K.; Rodriguez-Zas, S.L.; Everts, R.E.; Lewin, H.A.; Hurley, W.L.; Loor, J.J. Old and new stories: Revelations from functional analysis of the bovine mammary transcriptome during the lactation cycle. PLoS ONE 2012, 7, e33268. [CrossRef] [PubMed] 